\title{
Occurrence and
}

Distribution of Strontium

in Natural Water

GEOLOGICAL SURVEY WATER-SUPPLY PAPER 1496-D

This report concerns work done on behalf of the U.S. Atomic Energy Commission and is published with the permission of the Commission

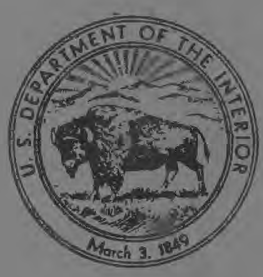

RECEIVED

FEB $4 \quad 1963$

WRD 


\section{Occurrence and}

Distribution of Strontium in Natural Water

y MARVIN W. SKOUGSTAD and C. ALBERT HORR

CHEMISTRY OF STRONTIUM IN NATURAL WATER

GEOLOGICAL SURVEY WATER-SUPPLY PAPER 1496-D

'This report concerns work done on behalf of the U.S. Atomic Energy Commission cnd is published with the permission of the Commission

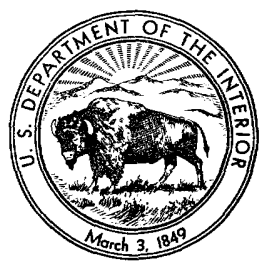


UNITED STATES DEPARTMENT OF THE INTERIOR

STEWART L. UDALL, Secretary

\author{
GEOLOGICAL SURVEY
}

Thomas B. Nolan, Director 


\section{CONTENTS}

\begin{tabular}{|c|c|}
\hline \multicolumn{2}{|r|}{ Page } \\
\hline Abstract. & 55 \\
\hline 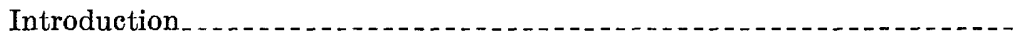 & 55 \\
\hline Sampling program_-... & 58 \\
\hline Analytical methods . . . . . . . & 58 \\
\hline Chemistry of strontium & 59 \\
\hline trontium content of water & 63 \\
\hline Surface water & 63 \\
\hline Ground water & 71 \\
\hline ummary _........... & 73 \\
\hline eferences cited & 74 \\
\hline
\end{tabular}

\section{ILLUSTRATIONS}

Figure 10. Average stron ium concentration in surface water........

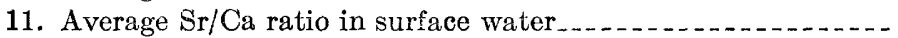

12. Average strontium concentration in total dissolved solids in surface water.

\section{TABLES}

TABLE 1. Physical properties of strontium and related elements.......-

2. Surface-water samples having a $\mathrm{Sr} / \mathrm{Ca}$ ratio greater than twice the median for all samples............

3. Surface-water samples having a strontium content greater than twice the median for all samples. . . . . . . . . . . . .

4. Chemical analyses of surface water........

5. Chemical analyses of ground water of low mineralization......

6. Chemical analyses of brines. . . .

7. $\mathrm{Sr} / \mathrm{Ca}$ ratios and strontium content in total dissolved solids.... 


\title{
CHEMISTRY OF STRONTIUM IN NATURAL WATER
}

\section{OCGURRENGE AND DISTRIBUTION OF STRONTIUM IN NATURAL WATER}

\author{
By Marvin W. Skougstad and C. Albert Horr
}

\begin{abstract}
Strontium, an alkaline-earth element chemically similar to calcium and magnesium, occurs in trace quantities in all natural water. Analysis of samples from 75 major rivers of the conterminous United States shows that the strontium concentration ranges from 0.007 to $13.7 \mathrm{ppm}$ (parts per million). The strontium concentration in the total dissolved solids carried by these waters ranges from a few hundredths of a percent to 0.37 percent. The greatest strontium concentration in surface water and in dissolved material occurs in the high-salinity streams of the Southwestern United States. In this area, characterized by relatively low annual rainfall, high evaporation rate, and low physical relief, the concentration of strontium in the streams is generally 2 to 3 times as great as in most other streams of the Nation.

The strontium content of ground water has a wider range than that of surface water. Of more than 175 ground-water samples analyzed, 60 percent contained less than $0.2 \mathrm{ppm}$, although some potable water samples contained as much as $50 \mathrm{ppm}$. One brine sample contained $2,960 \mathrm{ppm}$ of strontium.
\end{abstract}

\section{IN'TRODUCTION}

Studies of the occurrence of strontium in water have, with few exceptions, been limited to investigations of areas where unusually high strontium concentrations have been noted, or to the analysis of brines or highly mineralized waters containing appreciable amounts of strontium.

Odum (1951, p. 20-21) reported the strontium and calcium content of certain Florida waters, including 14 springs, 4 rivers, and 6 lakes and ponds. The strontium content of the springs generally ranged from 0.107 to $0.784 \mathrm{ppm}$ (part per million), although 1 spring was found to contain $6.308 \mathrm{ppm}$ of strontium and 2 spring samples contained less than $0.10 \mathrm{ppm}$. Strontium in rivers and lakes ranged from a few hundredths of a part per million to about $0.8 \mathrm{ppm}$.

Lohr and Love (1954, p. 624) noted the unusually high strontium content of three municipally-owned wells at Waukesha, Wis. Later, 
Nichols and McNall (1957) analyzed more than 380 samples in a comprehensive survey of the occurrence of strontium in municipal water supplies in Wisconsin. They found that water in the eastern part of the State generally contained more than $1.0 \mathrm{ppm}$ of strontium and that several wells in this area, including wells at Campbellsport, Greendale, Kaukauna, Menomonee Falls, Waukesha, and Wauwatosa, contained strontium in concentrations greater than $30 \mathrm{ppm}$. They tabulated the strontium content in the water supplies of 100 Wisconsin communities where the concentrations exceeded $1.0 \mathrm{ppm}$. Their analyses were made by a flame-photometric procedure using synthetic radiation buffers of a composition similar to the composition of the water analyzed. When the sample composition differed significantly from that of the synthetic buffer, an appropriate correction to the strontium value obtained was made.

Alexander, Nusbaum, and MacDonald (1954), in a study of the occurrence of strontium in the water supplies of 50 major cities of the United States, found only two sources which contained more than 1.0 $\mathrm{ppm}$. The maximum concentration found in any untreated surface or ground water used as a source for municipal supply was $1.9 \mathrm{ppm}$ in ground water at Wichita, Kans. The strontium content of the samples ranged from 0.0058 to $1.9 \mathrm{ppm}$. The analyses were made spectrographically and included determination of calcium and magnesium as well as strontium.

A more recent survey of the strontium content of the drinking water of seven cities (Chicago, Denver, Oak Ridge, Cincinnati, New York, Atlanta, and Charlottesville) was reported by Blanchard, Leddicotte, and Moeller (1958). They used a neutron-activation method to determine several minor elements, including strontium, and reported a range of strontium concentrations from 0.08 to 1.23 ppm.

Feulner and Hubble (1960) reported strontium concentrations in both surface and ground water in Champaign County, Ohio, where celestite-rich limestones and glacial deposits of Late Silurian age give rise to considerable amounts of strontium in ground water. Strontium concentrations ranging from a few tenths of a part per million to as much as $30 \mathrm{ppm}$ were found in the wells tested. Surface water, particularly that fed by springs or ground-water seepage from celestite-rich limestone aquifers, contained up to $2.1 \mathrm{ppm}$ of strontium. Two spring-discharge samples contained 8.7 and $9.0 \mathrm{ppm}$ of strontium.

The "Committee on World-Wide Runoff of Dissolved Solids," appointed by the International Association of Hydrology of the International Union of Geodesy and Geophysics, has undertaken a program involving the analysis of samples from about 70 major rivers of the world. Four samples from each river, each sample taken 
at a different time of the year and representing a different flow stage of the river, have been analyzed for about 20 chemical substances by conventional chemical methods. In addition, spectrographic trace-elements techniques were used to determine up to 25 additional minor elements, including strontium. Preliminary data (Durum, Heidel, and Tison, 1960) for the several U.S. rivers included in this study indicate a range of strontium concentration from $0.0075 \mathrm{ppm}$ (Apalachicola River, Fla.) to $0.802 \mathrm{ppm}$ (Colorado River at Yuma, Ariz.).

Except for these data, little information is available on the general occurrence and distribution of strontium in fresh water. Recently, however, considerable interest has developed in the occurrence of strontium in water, soils, plants, and foods, particularly in relation to the fallout hazards associated with the radioactive isotopes of strontium. There are four naturally occurring isotopes of strontium, the predominant one being strontium-88. These isotopes are not radioactive and are nontoxic, at least no more toxic than calcium, an essential element which in its behavior is chemically similar to strontium. Strontium, while being one of the more abundant of the minor elements, is much less abundant than calcium and probably seldom occurs in nature in concentrations which might be harmful.

Two strontium isotopes resulting from nuclear fission, strontium-89 and strontium-90, are among the most hazardous substances present in atomic fall-out or atomic-waste materials. They create a serious hazard to human and animal life when present in water or foods. A knowledge of the concentration levels of strontium in natural water, therefore, is of considerable interest for the evaluation of potential hazards in connection with fallout or atomic-waste disposal. There is little evidence that indicates a physiological preference for calcium with respect to strontium or vice versa. Strontium and calcium are probably assimilated by the body of man and by plants in close to the same relative proportion in which they occur in the water or food material ingested or available to the organism. Because there is no physiological or chemical distinction between strontium-90 and the nonradioactive isotopes of strontium, the presence of natural strontium effectively dilutes the radioactive variety and reduces the amount of strontium-90 taken up by body tissue.

In order to have more extensive, accurate data on the concentration levels of strontium which occur in natural water, the U.S. Geological Survey has made a study of its occurrence and distribution in the natural waters of the United States. The study was made on behalf of the U.S. Atomic Energy Commission and was carried out under the direction of S. K. Love, Chief, Quality of Water Branch, U.S. Geological Survey. 


\section{SAMPLING PROGRAM}

A program was established which provided for the sampling of 75 of the major rivers and streams of the conterminous United States. Several large rivers were sampled at more than one point so that a total of 85 different sampling points was included. Most of the sampling sites selected are regularly operating stations of the Quality of Water Branch of the Survey. An attempt was made to obtain three samples at each site over a period of several months or a year, in order to obtain samples representing high-, median- , and low-flow conditions at each site. At a few sites this was not possible because they were not sampled on a regular schedule, and multiple sampling was impractical. No attempt has been made to obtain exact flow data, and the designations "high," "medium," and "low" flow are to be considered as representing relative flow conditions only.

The discharge or flow rate varies widely for certain rivers and very little for others. Thus, for some rivers the difference between high and low flow may be very little, while for others it is large. Detailed data on flow rates for most of the rivers included in this report may be found in the U.S. Geological Survey Water-Supply Paper series "Surface Water Supply of the United States," published annually in 14 parts.

A chemical analysis was made of each sample collected. Most of these analyses were made in the laboratory of the district office operating the sampling station and collecting the sample for this study. The district office then transmitted a part of the sample, together with the analytical report, to the Denver Quality of Water laboratory of the Survey where all strontium analyses were made (table 4).

Although this study was primarily intended to provide a survey of strontium concentrations in surface water, a considerable number of ground waters, including some brines, mineral waters, and springs, and other miscellaneous water samples were analyzed for strontium when such samples were available. These additional samples were obtained as a result of sampling for other purposes, but the results of chemical analyses of these samples (including strontium) are included in this report (table 5). The analyses of several brines and highly mineralized waters are also included (table 6).

\section{ANALYTICAL METHODS}

Samples containing more than $1.0 \mathrm{ppm}$ of strontium were analyzed by a direct flame-photometric method, utilizing a radiation buffer to minimize the effect of variation in sample composition with respect to other constituents. The determination of strontium by direct 
flame photometry is not sufficiently sensitive for water whose strontium concentration is less than $1.0 \mathrm{ppm}$, and two techniques were used for analysis of those waters. One, a flame-photometric method, involved a tenfold concentration of the cationic constituents in the sample by means of a strongly acidic cation-exchange resin before the determination of strontium. By this method, as little as $0.02 \mathrm{ppm}$ of strontium could be detected with certainty. The ion exchange technique, in addition to accomplishing a tenfold concentration of the sample, had the added advantage that anionic interferences such as those from sulfate and phosphate were eliminated, and the final solutions used for the flame-photometric determination were of uniform anionic composition. The flame photometric procedures are described in detail by Horr (1962).

The second method used to determine strontium in samples containing less than $1.0 \mathrm{ppm}$ of strontium was a spectrographic method. The spectrographic copper-spark technique used permitted detection of $0.005 \mathrm{ppm}$ of strontium without prior concentration of the sample and had the added advantage that 20 to $30 \mathrm{ml}$ of sample would suffice for the analysis. The spectrographic method was developed solely for the determination of trace amounts of strontium in dilute water and is not considered reliable for the analysis of water containing more than 500 to $600 \mathrm{ppm}$ of dissolved solids. A detailed description of the spectrographic procedure is given by Skougstad (1961).

\section{CHEMISTRY OF STRONTIUM}

Strontium, atomic number 38, is the fourth member of the Group II elements, the alkaline-earth metals. The electron distribution in the strontium atom $\left(1 \mathrm{~s}^{2} 2 \mathrm{~s}^{2} 2 \mathrm{p}^{6} 3 \mathrm{~s}^{2} 3 \mathrm{p}^{6} 3 \mathrm{~d}^{10} 4 \mathrm{~s}^{2} 4 \mathrm{p}^{6} 5 \mathrm{~s}^{2}\right)$ determines its universal divalency in its compounds. This is characteristic of all elements in this group which have no partially filled subshells, and whose outermost electron shell is a completed s-shell. The nucleus may contain $46,48,49$, or 50 neutrons. Thus, there are 4 stable isotopes of strontium having mass numbers of $84,86,87$, and 88 . The natural distribution of these 4 isotopes gives rise to an average atomic weight for strontium of 87.63 and an equivalent weight of 43.82 .

Although no radioactive isotopes of strontium exist in nature, as many as 10 artificially produced isotopes have been identified. The most familiar of these are the isotopes of mass number 89,90 , and 91 , which are a part of the material that results from atomic fission.

The other alkaline-earth elements are beryllium $(Z=4$, at. $w \mathrm{t}=$ 9.013), magnesium $(Z=12$, at. $w \mathrm{t}=24.32)$, calcium $(Z=20$, at. $\mathrm{wt}=40.08)$, barium $(Z=56$, at. $\mathrm{wt}=137.36)$, and radium $(Z=88$, at. $\mathrm{wt}=226.05)$. Of the alkaline-earth elements, calcium and magnesium are by far the most abundant, both in the earth's crust and in the 
hydrosphere. Next in general abundance are strontium and barium, of ten of the same order of magnitude, and finally beryllium and radium, which occur in exceedingly small amounts relative to the others.

Physical properties of the several elements most closely resembling strontium (table 1) indicate that strontium should be intermediate between calcium and barium with respect to its chemical behavior, and in many instances should resemble potassium. This is indeed true, and strontium is commonly found in both calcium and barium minerals and, to some extent, even in potassium minerals, as a result of replacement of ions of these elements in the crystal lattice of their minerals. Strontium occurs in barite, where it replaces barium, and in aragonite, calcite, gypsum, and anyhdrite, where it replaces calcium. No doubt the widespread distribution of strontium in trace amounts in igneous rocks is due to its ability to substitute for potassium, particularly in potassium feldspars, or for calcium in other igneous rock minerals.

TABLE 1.-Physical properties of strontium and related elements

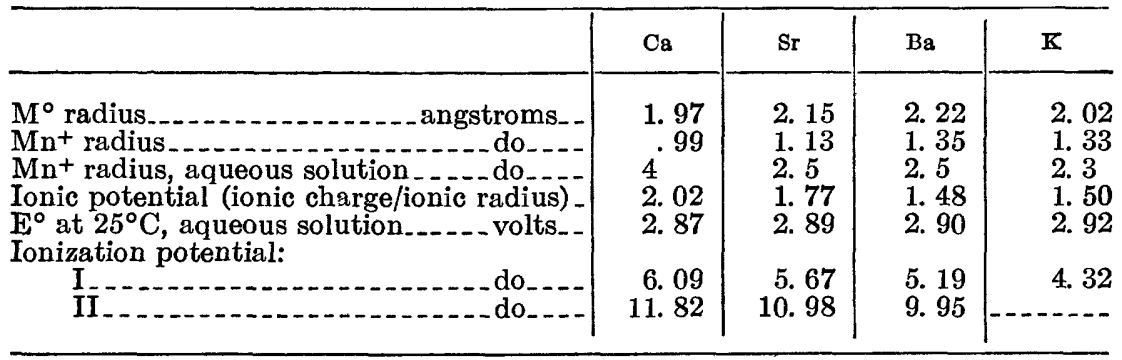

Strontium forms chemical compounds analagous to those of calcium and barium. The properties of such compounds are usually intermediate between those of the same compounds of calcium and barium. Thus, the carbonates, sulfates, chromates, and phosphates of all three metals are sparingly soluble in water, the solubility decreasing with increasing atomic number. In fact, the very low solubility of barium salts restricts the movement of barium through soils and by water transport. A few parts per million of sulfate in water, for example, precludes the possibility of the presence of much barium. Strontium sulfate, however, is much more soluble, hence appreciable amounts of strontium may exist in water containing significant concentrations of sulfate.

Strontium finds its way into natural water in much the same way as does calcium. Through normal weathering processes, water in contact with soil and rock materials dissolves appreciable amounts of minerals and other constituents largely through the action of hydrogen 
ions carried by the water. The carbonic acid-bicarbonate equilibrium in water provides a supply of hydrogen ions and permits retention of the reaction products in solution, as in the case of strontium and calcium, through the formation of soluble bicarbonates. Although carbonic acid, resulting from dissolved carbon dioxide, is a principal factor in causing attack on soil and rock particles, other factors are also effective. Organic solutes found in soil moisture, acid clays, strong mineral acids (particularly sulfuric and sulfurous acids formed by oxidation of sulfide minerals), and organic chelating compounds may also be effective under certain conditions.

Strontium in natural water may be removed or redeposited by several mechanisms and reactions. Strontium carbonate is less soluble than calcium carbonate and precipitates at a $\mathrm{pH}$ below that at which calcite precipitates. When calcium carbonate precipitates, and if strontium is present in the same solution, some strontium will almost certainly accompany the calcium by coprecipitation, even though the solubility product of strontium carbonate may not be exceeded. This is true also when other substances, such as ferric hydroxide, precipitate from water. Some strontium may be caught or adsorbed to the colloidal precipitate and dragged down with it

Other insoluble strontium compounds, such as sulfates or phosphates, may be formed. Strontium may also be adsorbed through ion exchange with clay minerals, or it may exchange with calcium minerals such as calcite or aragonite. In this respect, the relatively small radius of the hydrated strontium ion indicates a greater tendency for exchange than the larger calcium ions. This is generally true and it has been observed that strontium is more strongly held by exchange materials than is calcium.

The sources of strontium in natural water are mainly the trace amounts of strontium found in nearly all limestones and widely distributed in igneous and metamorphic rocks. When the strontium in in water is derived from these sources, the relative amounts of strontium and calcium do not usually differ greatly from their proportions in the rock material. Certain natural waters have much higher $\mathrm{Sr} / \mathrm{Ca}$ ratios ( $\mathrm{Sr}$ atoms per 1,000 $\mathrm{Ca}$ atoms) and indicate that the water has been in contact with strontium-mineral deposits, either celestite $\left(\mathrm{SrSO}_{4}\right)$ or strontianite $\left(\mathrm{SrCO}_{3}\right)$. Such deposits usually occur as beds or lenses in limestone deposits or in anhydrite or gypsum. Celestite frequently occurs disseminated in limestone and dolomite.

Probably relatively few waters are saturated with respect to either strontium carbonate or strontium sulfate. The amount of strontium present is largely controlled by its abundance in the rock material that has gone into solution. 
The chemical similarity of strontium and calcium suggests that correlations may exist between these two elements with respect to their occurrence in the rocks and minerals. Turekian and Kulp (1956), reporting on the distribution of strontium in various rock materials, offer evidence that there is a direct relationship between the calcium content of granites and the amount of strontium present in these granites. They found that whereas all granitic rocks contain, on an average, an estimated 0.0285 percent strontium, granodiorites containing 1.0 to 5.0 percent calcium contain an estimated average of 0.0440 percent strontium. On the other hand, granites having 0.1 to 1.0 percent calcium contain an average of 0.0100 percent strontium. Previous estimates of the average strontium content of granitic rocks, 0.0090 percent (Noll, 1934) and 0.0120 percent (Hevesy and Wurstlein, 1934), were considerably lower. It is generally apparent, however, that in granitic rocks the amount of strontium increases as the amount of calcium increases.

These same investigators also estimated the average strontium content of basaltic rocks to be about three times as great as previously reported and found an average of 0.0465 percent strontium in all basalts, a figure that is considerably higher than the average for granites (0.0285 percent) and slightly higher than the average for high-calcium granites $(0.0440$ percent).

The average strontium content of all limestones was found by Turekian and Kulp (1956) to be 0.0610 percent; shales contained only about one-half of this amount. They concluded that sandstones probably contain, on an average, no more than 0.0020 percent strontium.

On the basis of these observations, some estimate of the probable occurrence of strontium in water might be projected. That is, in water draining areas where surficial geology consists primarily of basalt or sedimentary rocks, the proportion of strontium to calcium would be expected to be significantly less than in water draining areas of granitic igneous rocks. Such an extension of the geologic implications must be tempered with consideration of additional factors which can affect the behavior of strontium when it is dissolved in water. The movement of water through soil and rocks, involving contact with clay minerals and finely divided sediment material in the soil and in suspension in a stream, permits opportunity for several types of reactions which may alter the ratio of strontium to other major constituents in the water. Turekian and Kulp were unsuccessful in their attempts to correlate the occurrence of strontium with potassium. 


\section{STRONTIUM CONTENT OF WATER}

\section{SURFACE WATER}

All surface-water samples collected as a part of this study contained a detectable amount of strontium (more than $0.005 \mathrm{ppm}$ ). The ligher strontium concentrations were found in the streams of the Southwest, including eastern Arizona, New Mexico, western Oklahoma, and northern and western Texas, where the total dissolvedsolids content of the surface waters is also the highest of any area of the conterminous United States. In many places in this area rocks of ratlier higl solubility occur at or near the land surface. The low average-annual precipitation together with high rates of evaporation and loss of surface water to ground-water recharge tends to reduce stream-discharge rates downstream from the source and to increase the dissolved-solids concentration carried by the stream. The high-salinity streams of this area also carry proportionally more strontium, usually $1.5 \mathrm{ppm}$ or more, and some as much as 5.4 and $9.5 \mathrm{ppm}$, as in the samples from the Double Mountain Fork and the Salt Fork of the Brazos River near Aspermont, Tex., respectively (table 4).

By contrast, streams of most of the Atlantic slope basins, Southeastern United States, the upper Great Lakes region, and the Pacific Northwest contain relatively low concentrations of strontium. This fact coincides witl observations which may be made on the cliaracteristics of rivers and streams of these areas. In general the salinity of water draining these areas is low, the average annual rainfall is relatively higl, the evaporation rate is low, and the loss from streams due to ground-water recharge is low. Rarely do streams in these areas contain more than $0.5 \mathrm{ppm}$ of strontium and frequently the strontium content is much less, especially during periods of high discliarge.

Rivers of the rest of the Nation generally contain between 0.5 and $1.5 \mathrm{ppm}$ of strontium. Several exceptions to these generalizations may be noted; the exceptions usually involve higher concentrations of strontium in a stream than would be expected from the generalizations just stated. One sucli exception is the high concentration of strontium in the Maumee River, Ohio. Samples taken at Waterville (table 4) contained 0.44 to $1.0 \mathrm{ppm}$ of strontium. (An additional sample, containing $1.4 \mathrm{ppm}$ of strontium, was analyzed but was not included in table 4 because of lack of otlier data.) This is considerably more than most of the rivers of the midcontinent area, more than was observed in samples collected from the Ohio, Kentucky, Wabash, and Cumberland Rivers, for example. Feulner and Hubble (1960) have pointed out the high strontium 
content of certain ground waters in an area of northwestern Ohio, and the celestite deposits and celestite-rich limestones and glacial deposits of that area. These celestite-bearing limestones of Late Silurian age extend north and northwest of Champaign County, Ohio, and no doubt contribute significant amounts of strontium to streams which are tributaries of the Maumee and which, therefore, serve to increase strontium content in the Maumee even as far downstream as Waterville, which is close to the mouth of the river.

Another obvious exception resulting from localized conditions involves an area along the east coast of Florida. Odum (1951, p. 20-21) reported strontium concentrations in water from several springs and spring-fed rivers which are higher than might be expected on the basis of the generalizations previously made. The results of the present study also indicate the presence of somewhat higher strontium concentrations in certain of the Florida rivers sampled, particularly rivers along the eastern coast. Thus, the St. Johns River showed concentrations of strontium ranging from 0.68 to $1.1 \mathrm{ppm}$. Other Florida rivers sampled contained 0.029 to $0.11 \mathrm{ppm}$ of strontium, which is in accord with the expected concentration. The higher strontium concentration found in samples taken in the eastern part of the State may be attributed to underlying limestones containing a high concentration of strontium and to a significant flow of ground water to surface streams from these permeable limestone formations.

The average strontium concentration of samples obtained at each site are shown in figure 10.

Strontium-calcium ratios (Sr atoms per 1,000 Ca atoms) were calculated for all samples in which both ions were determined (table 7). The ratios ranged from 0.40 to 15.75 . Calculation of an average $\mathrm{Sr} / \mathrm{Ca}$ ratio has little significance because of the variability among the samples and the great irregularity in distribution of the sampling sites. However, it may be pointed out that the $\mathrm{Sr} / \mathrm{Ca}$ ratios in three of the rivers sampled were exceptionally high: the St. Johns River near Cocoa, Fla.; the Canadian River at Logan, N. Mex., and the Paria River, at Lees Ferry, Ariz. Two samples from the Paria River had ratios of 10.5 and 4.19; the river is one of the sources of the Yuma Main Canal, one sample of which also had an unusually high $\mathrm{Sr} / \mathrm{Ca}$ ratio (11.2) that probably reflected the upstream sources.

A median-flow sample from the Brazos River at Richmond, Tex., also showed an unusually high $\mathrm{Sr} / \mathrm{Ca}$ ratio. Two other samples, one at high flow and one at low flow showed ratios of 2.60 and 3.68 , respectively, whereas the median-flow sample had a ratio of 12.6. This sample also differed in other respects from the other two samples from this river. Sodium and chloride concentrations were approximately 6 times the amount found in the other 2 samples. Concentrations of 


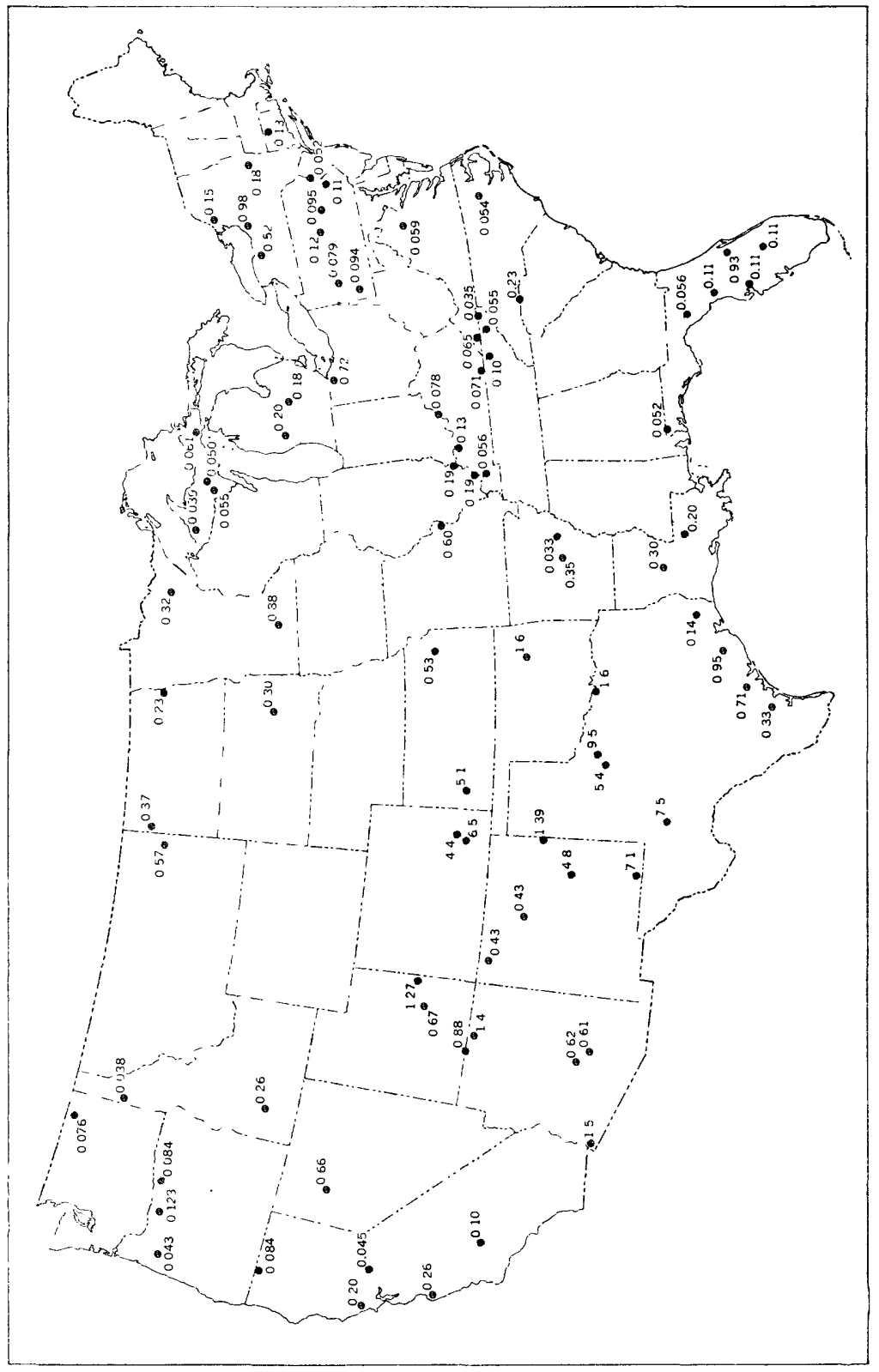

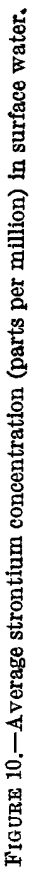


the other major constituents did not increase to nearly the same extent: calcium and magnesium only about twice, potassium by about one-half, sulfate about three times, and bicarbonate only very little. This suggests drainage of salt water bearing significant strontium, since the strontium concentration increased about five times.

The median $\mathrm{Sr} / \mathrm{Ca}$ ratio for all samples was 3.2. Those samples which had a ratio greater than twice the median are listed in table 2.

$\mathrm{T}_{\mathrm{ABLE}}$ 2.-Surface-water samples having a $\mathrm{Sr} / \mathrm{Ca}$ ratio greater than twice the median for all samples

\begin{tabular}{|c|c|c|c|}
\hline River & Location & Flow stage & $\begin{array}{c}\text { Sr in total } \\
\text { dissolved } \\
\text { solids (percent) }\end{array}$ \\
\hline St. Johns & Cocoa, Fla & High. & 16. 3 \\
\hline Do & do & Median & 15. 7 \\
\hline Canadian. & Logan, N. Mex & High & 15. 0 \\
\hline Do & . - do do & Median. . . & 14. 7 \\
\hline Do & .... do & Low ......... & 14. 4 \\
\hline Do_ & do & $\ldots$ do & 14. 0 \\
\hline Brazos $_{\ldots}$ & Richmond, Tex & Median & 12.6 \\
\hline Arkan & Tulsa, Okla_- & $\ldots$.....do_.. & 11. 4 \\
\hline Yuma, Main Canal & Yumá, Ariz.. & . do _. & 11.2 \\
\hline St. Johns ..... & Cocoa, Fla & Low $_{-}$ & 11. 1 \\
\hline Canadian .... & Logan, N. Mex.. & Median & 11.0 \\
\hline Pari: & Lees Ferry, Ariz. & Low. & 10.5 \\
\hline Car & Logan, N. Mex.- & ... _do_. & 9.7 \\
\hline Main Canal... & Yuma, Ariz & & 8. 51 \\
\hline Gre & River, Utah. & High_ & 8. 47 \\
\hline $\mathrm{Nec}$ & Evadale, Tex ... & Low & 8. 37 \\
\hline $\mathrm{H}$ & Rye Patch, Ne & .....do_ & 8. 22 \\
\hline A & Tulsa, Okla & do do... & 7. 7 \\
\hline Purg & Lus Animas, Colo. & & 7. 7 \\
\hline Kis & Okeechobee, Fla & High........ & 7. 3 \\
\hline Rappahannock & Remington, W. Va_- & $\ldots . .$. & 7. 13 \\
\hline Peco & Puerto de Luna, N. Mex & Low $_{-}-$ & 7. 77 \\
\hline Rio Grande...- & San Ildefonso, N. Mex & Median .... & 7. 60 \\
\hline San Juan & Archuleta, N. Mex & Low ....... & 6. 70 \\
\hline Sal & Stewart Mt. Dam, Ariz $\ldots \ldots$ & High._- & 6. 64 \\
\hline American . . ...... & Fair Oaks, Calif & $\ldots$ & 6.50 \\
\hline
\end{tabular}

It will be observed that practically all of the rivers with unusually high $\mathrm{Sr} / \mathrm{Ca}$ ratios are located in the southwest and along the east coast of Florida. A single exception is the Rappahannock River. One sample taken at approximately median flow showed a ratio twice the average ratio observed on three other samples taken over a period of several months. The chemical quality in the Rappahannock at Remington does not vary significantly throughout the year. However, it should be noted that in the one sample which showed a high $\mathrm{Sr} / \mathrm{Ca}$ ratio, the sulfate concentration was also proportionally much greater than the median or nominal concentration of sulfate for this stream. While the concentrations of $\mathrm{Ca}, \mathrm{Mg}, \mathrm{Na}, \mathrm{K}, \mathrm{HCO}_{3}$, and $\mathrm{Cl}$, were about the same or slightly below the median concentration for 
these ions, the sulfate concentration in this particular sample was about double the median for this ion. This would indicate a possible pollution of the stream with $\mathrm{SrSO}_{4}$ at or about the time of sampling, or a stream entering the Rappahannock above the sampling point and draining an area containing strontium-rich minerals.

Two rivers in Florida, both draining eastern coastal areas, showed unusually high $\mathrm{Sr} / \mathrm{Ca}$ ratios. Ratios of $16.3,15.7$, and 11.1 were obtained on 3 samples from the St. Johns River near Cocoa, Fla. Two of these, however, are low-flow samples since the discharge measurements, 411 and $357 \mathrm{cfs}$ (cubic feet per second), respectively, are much below the 1958 water-year median of $1,368 \mathrm{cfs}$, and not much greater than the minimum of 218 crs for that year. The 1958 water-year maximum discharge was 3,990 cfs and occurred on October 4-5. The $\mathrm{Sr} / \mathrm{Ca}$ ratio for the high-flow sample, 16.3. at $2,323 \mathrm{cfs}$, is only slightly larger than the ratio for one of the low-flow samples, 15.7 at $411 \mathrm{cfs}$.

The Kissimmee River, sampled near Okeechobee, Fla., also showed a fairly high $\mathrm{Sr} / \mathrm{Ca}$ ratio in the single sample obtained at this site. Although the discharge data are not available for this sample, the date of sampling, May 1-10, indicated that it was probably sampled at a time of about median flow. The chemical analysis of this sample shows a fairly high magnesium content and considerable sodium chloride, although the total concentration of dissolved solids is low and the water may be classified as a soft water.

$\mathrm{Sr} / \mathrm{Ca}$ ratios in rivers of the rest of the Nation ranged from 0.40 to 6.4. There is no consistent correlation between discharge and the $\mathrm{Sr} / \mathrm{Ca}$ ratio. In some streams the ratio increases with a decrease in discharge rate while for others the opposite is true. In general, the greatest variations in the $\mathrm{Sr} / \mathrm{Ca}$ ratio in a single river sampled at different flow rates occurred when the ratio was much larger than the median. Thus, the $\mathrm{Sr} / \mathrm{Ca}$ ratio in 6 samples from the Canadian River at Logan, N. Mex., ranged from 9.7 to 15.0. Similarly, the ratio in the Arkansas River, at Tulsa, Okla., ranged from 6.6 to 11.4 .

In some rivers, the $\mathrm{Sr} / \mathrm{Ca}$ ratio does not vary appreciably with discharge rate, as, for example, the Cumberland, Monongahela, St. Lawrence, Lehigh, Mohawk, Oswego, Susquehanna, and Roanoke Rivers.

The average $\mathrm{Sr} / \mathrm{Ca}$ ratio for samples collected at each site is shown in figure 11.

Another indication of the general distribution of strontium in surface water may be obtained by calculating the strontium content in the total dissolved material carried by the river. This information was available (table 7) for the great majority of samples. Figure 12 shows the distribution of values. The strontium content ranged $659997-63-3$ 


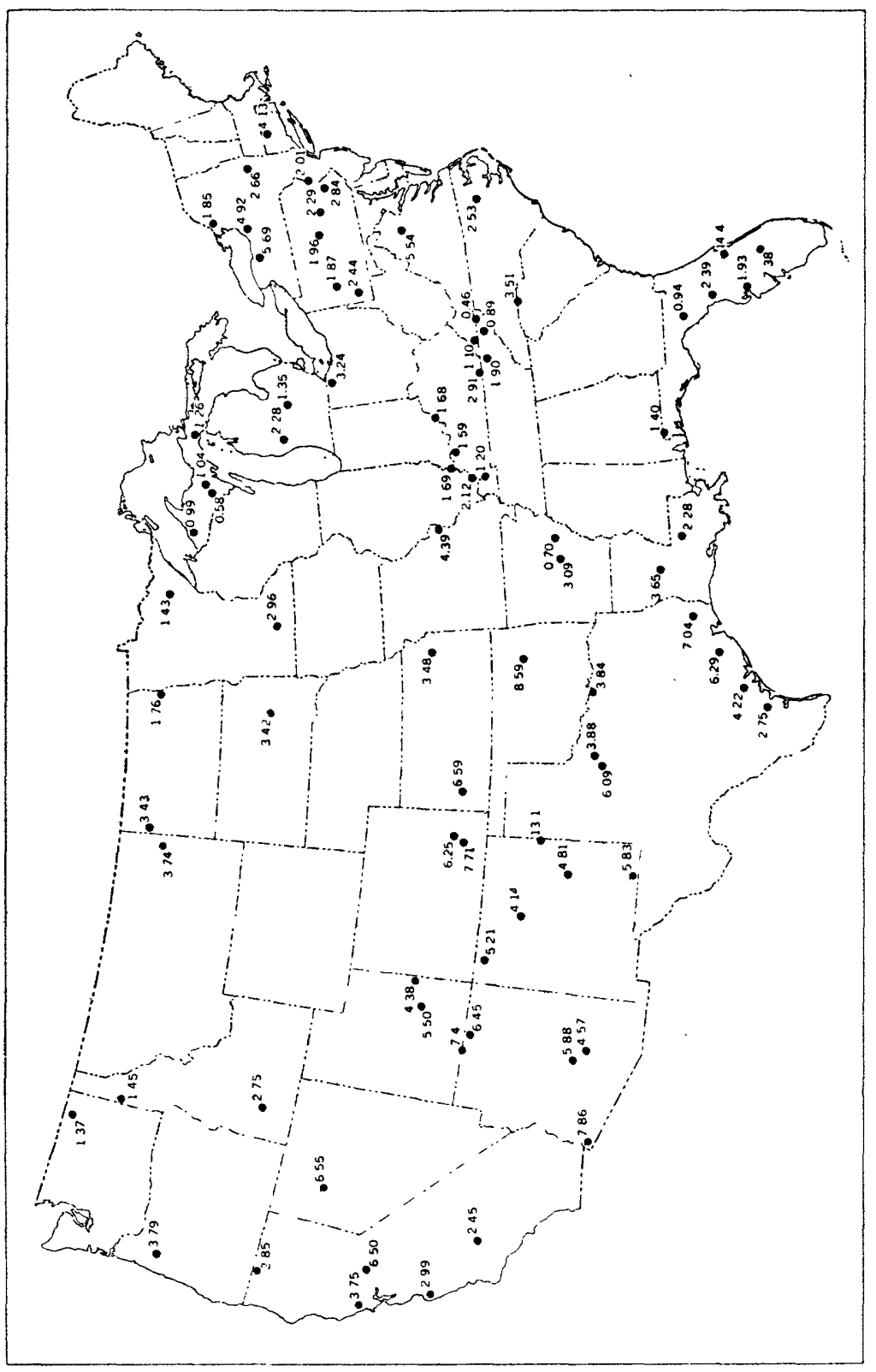

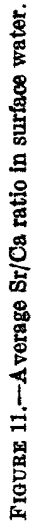




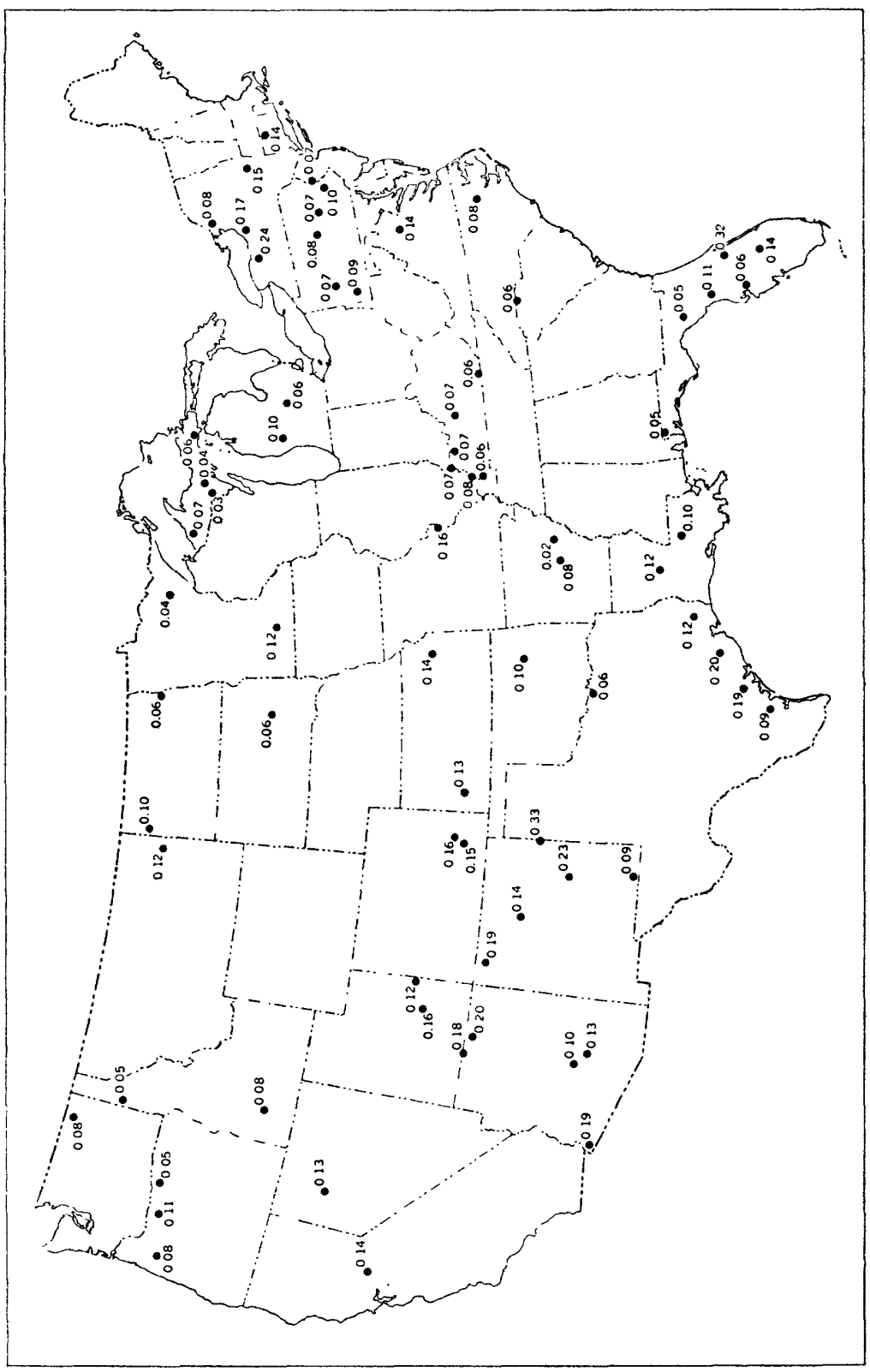


from 0.01 to 0.38 percent, 0.09 percent being the median for all samples. Very low concentrations of strontium were found in the Embarrass (0.03, 0.04 percent), Escanaba (0.04 percent), and Ford (0.03 percent) Rivers, all in northern Minnesota or Michigan, and in the Escambia River (0.05 percent), in Florida. The White River, sampled at Clarendon, Ark., also had a very low concentration of strontium, 0.03, 0.02, and 0.02 percent being found in 3 samples analyzed. A high-flow sample from the James River at Huron, S. Dak., contained only 0.03 percent strontium, whereas near-medianflow and low-flow samples from this river contained 0.07 and 0.08 percent, respectively.

There is no general correlation between flow and the concentration of strontium. Thus, the concentration of strontium in the Pecos River at Puerto de Luna was observed to vary threefold, from 0.12 to 0.36 , over a period of a year. Similarly the percentage of strontium in the Brazos River at Richmond, Tex., varied from 0.11 at high flow $(42,980 \mathrm{cfs})$ to 0.35 at median flow $(4,685 \mathrm{cfs})$ and to 0.13 at low flow (the unusual chemical characteristics of the median-flow sample have been noted on page 75).

Many other rivers showed only slight variation in percentage of strontium throughout the year, as, for example, the Yakima River at

$\mathrm{T}_{\mathrm{ABL}}$ 3.-Surface-water samples having a strontium content greater than twice the median for all samples

\begin{tabular}{|c|c|c|c|}
\hline River & Location & Flow & $\begin{array}{l}\text { Sr in total dis- } \\
\text { solved solids } \\
\text { (Percent) }\end{array}$ \\
\hline Canadian. & Logan, N. Mex. & High. & 0.38 \\
\hline Pecos_.. & Puertó de Luna, N. Mex & Low _ & .36 \\
\hline Brazos...... & Richmond, Tex.............. & Median & .35 \\
\hline St. Johns.. & Cocoa, Fla & High. & .32 \\
\hline Canadian. & Logan, N. Mex & Median & .31 \\
\hline Green & Green River, Utah. & High... & .31 \\
\hline Can & Logan, N. Mex... & Low.. & .29 \\
\hline Yuma, Main Canal & Yuma, Ariz & Mediaı & .27 \\
\hline Genesee...... & Rochester, N. Y. & & \\
\hline Paria & Lees Ferry, Ariz & Low & .2 \\
\hline Colorado $\ldots . .$. & - do do & High.. & \\
\hline San Juan & Archuleta, N. Mex & Low & .23 \\
\hline Genesee_. & Rochester, N.Y. & ..... do & $\begin{array}{l}.23 \\
.22\end{array}$ \\
\hline Yuma, Main Canal. & Yuma, Ariz & $-2-2-2$ & .21 \\
\hline Colorado & Lees Ferry, Ariz & Low & .20 \\
\hline Gila_... & Kelvin, Ariz & High...- & .20 \\
\hline Pecos. & Puerto de Luna, N. Mex. & Low ..... & .20 \\
\hline Rio Grande. & San Ildefonso, N. Mex & & \\
\hline Gila_... & Kelvin, Ariz & Median & .19 \\
\hline Guadalupe - & Victoria, Tex.. & High_......- & .19 \\
\hline $\begin{array}{l}\text { Mississipp1 . . } \\
\text { Oswego } \ldots \ldots\end{array}$ & $\begin{array}{l}\text { St. Louis, Mo } \\
\text { Oswego, N.Y. }\end{array}$ & Median & .19 \\
\hline
\end{tabular}


Northport, Wash., the White River at Clarendon, Ark., the Red River of the North at Grand Forks, N. Dak., and the Delaware and Lehigh Rivers, $\mathrm{Pa}$. The strontium content trends to fluctuate to a greater extent in those rivers in which it is in excess of 0.1 percent of the total dissolved-solids content. If the strontium content in a river is close to, or below, the observed median for all rivers sampled, the variations in strontium content in samples taken throughout the year and at different flow stages are more likely to be small.

Surface-water samples found to have a strontium content which is more than twice the median for all samples analyzed are shown in table 3 .

\section{GROUND WATER}

In addition to the surface-water sampling program, 175 samples of ground water were analyzed for strontium. Unlike the surface-water program, however, the ground-water samples were not obtained by a sampling program planned for this purpose, but were analyzed as they became available to the laboratory from various sources. Most of the ground-water samples were taken from public water supplies and were obtained in connection with other current projects. These samples were analyzed only by the direct flame-photometric procedure, whose limit of sensitivity is $0.2 \mathrm{ppm}$ of strontium. No attempt was made to determine strontium in samples containing less than this amount. Many of the samples did contain less than $0.2 \mathrm{ppm}$ of strontium (table 5).

A wide range in strontium concentration was observed in ground water. The unusually high concentration of strontium in ground water of east-central Wisconsin has previously been reported by Lohr and Love (1952) and by Nichols and McNall (1957). The $\mathrm{Sr} / \mathrm{Ca}$ ratios calculated from the chemical analyses of water from 3 Waukesha, Wis., wells reported by Lohr and Love are 396, 285, and 208. These values are higher, by a factor of 100 to 300 , than the maximum ratio calculated for any surface water sampled in the present study. The concentration of strontium in the dissolved solids of these samples is also exceptionally high: 11.8 percent, 9.8 percent, and 7.9 percent, respectively.

Two samples obtained from this area of Wisconsin for the present project contained 36.0 to $24.4 \mathrm{ppm}$ of strontium. These samples, one from a drilled well at Campbellsport in Fondulac County, the other from a drilled well at Kaukauna in Outagamie County, were not from the area of highest previously observed strontium concentrations. Nevertheless the Campbellsport sample had a $\mathrm{Sr} / \mathrm{Ca}$ ratio of 162 and contained 5.9 percent strontium, and the Kaukauna sample a $\mathrm{Sr} / \mathrm{Ca}$ ratio of 65.5 and a strontium content of 3.16 percent. 
Feulner and Hubble (1960), in their study of the occurrence of strontium in surface and ground water of Champaign County, Ohio, found that, of 22 drilled-wells sampled, the water of 7 contained between 17 and $20 \mathrm{ppm}$ of strontium and 1 contained $30 \mathrm{ppm}$. The $\mathrm{Sr} / \mathrm{Ca}$ ratios in these 8 samples ranged from 89.7 to 132 , and the strontium content in the dissolved solids ranged from 4.4 to 5.4 . Other samples from this group of 22 , with but one exception, had $\mathrm{Sr} / \mathrm{Ca}$ ratios within the range generally found in surface water of the conterminous United States. However, in only two of the Champaign County wells was the strontium content within the range found in the Nation's surface waters.

The data of Feulner and Hubble are somewhat less complete for surface water of the sane area, particularly for samples which were found to contain in excess of $1 \mathrm{ppm}$ of strontium. For the most part, however, the surface-water samples showed $\mathrm{Sr} / \mathrm{Ca}$ ratios of from 1.2 to 19.0 , calculated on the basis of their reported results. The analyses of samples from two springs draining into Nettle Creek differed markedly from the others. The $\mathrm{Sr} / \mathrm{Ca}$ ratios, 56 and 60 , are several times as large as those found in most surface water.

The chemical data (including strontium concentrations) for groundwater samples are given in table 5. Most of the samples analyzed contain less than $0.2 \mathrm{ppm}$ of strontium. Ground-water samples collected from Iowa and Kansas, however, contained more. Of 15 samples collected in Iowa, 4 contained less than $0.2 \mathrm{ppm}$ of strontium. The strontium content of the other 11 samples ranged from 0.8 to $8.8 \mathrm{ppm}$. Of 15 samples collected from different wells in Kansas, 5 contained $0.2 \mathrm{ppm}$, or less, of strontium, 9 contained from 0.8 to 1.6 ppm, and 1 sample, from Eskridge, in Wabaunsee County, contained $9.2 \mathrm{ppm}$.

Several samples from ground-water sources in Eddy County, N. Mex., also contained considerable amounts of strontium, as much as $8.0 \mathrm{ppm}$ in 1 sample. A single sample from Wayne County, N.Y., contained $13 \mathrm{ppm}$ of strontium.

Sixty percent of the ground-water samples tested contained 0.2 $\mathrm{ppm}$, or less, of strontium. Certain brine samples, however, contained unusually high concentrations; as much as $2,960 \mathrm{ppm}$ in a sample from a brine source at Midland, Mich. Another sample from a brine well at Orlando, W. Va., contained 2,200 ppm of strontium. 
Except for these brines, however, the strontium content generally ranged from 0.2 to $59 \mathrm{ppm}$, and only 9 samples of approximately 175 analyzed contained more than $10 \mathrm{ppm}$.

The chemical analyses of several brine samples are shown in table 6. The $\mathrm{Sr} / \mathrm{Ca}$ ratio in these samples ranges from 4.4 to 28.6. These brines also show a high concentration of strontium in the dissolved solids, ranging from 0.07 to 0.84 percent. One brine sample, containing 0.07 to 0.84 percent. One brine sample, containing 0.07 percent strontium in the dried residue, was close to the median (0.09 percent) for all surface water tested. Another sample contained only slightly more strontium, whereas other brine samples contained from 2 to nearly 5 times the median strontium content in surface water. The maximum strontium content in any surface water tested was 0.38 in a sample from the Canadian River, at Logan, N. Mex. Four brine samples contained from 0.25 to 0.33 percent, and 2 samples contained 0.6 and 0.84 percent.

\section{SUMMARY}

A survey of the occurrence of strontium in the major rivers of the Nation shows that concentrations may range from $0.007 \mathrm{ppm}$ to nearly $15 \mathrm{ppm}$. The percentage of strontium in the total dissolvedsolids content carried by these streams ranges from 0.01 to 0.38 . Relatively high concentrations of strontium occur in the streams of the southwest, where concentrations generally exceed $1.5 \mathrm{ppm}$ and are locally as high as $13.7 \mathrm{ppm}$. Streams of this area are generally of relatively high salinity. They drain areas of low annual rainfall and of generally high evaporation losses.

Streams of the Pacific Northwest, most of the Atlantic Coastal Plain, and northern Minnesota and Michigan generally contain only small concentrations of strontium, usually less than $0.5 \mathrm{ppm}$, and frequently as little as $0.01 \mathrm{ppm}$ or less.

Strontium concentrations in ground water vary greatly. Potable waters may contain up to $50 \mathrm{ppm}$. but certain brines from wells and other highly mineralized waters may contain several thousand parts per million. In addition to previously known areas of ground waters with a relatively high strontium content in eastern Wisconsin and west-central Ohio, several ground-water samples from Iowa, Kansas, and New Mexico were found to contain more than $3.0 \mathrm{ppm}$ of strontium. 


\section{REFERENCES CITED}

Alexander, G. V., Nusbaum, R. E., and MacDonald, N. S., 1954, Strontium and calcium in municipal water supplies: Am. Water Works Assoc. Jour., v. 46, p. 643-654.

Blanchard, R. L., Leddicotte, G. W., and Moeller, D. W., 1958, Neutron activation analysis of drinking water: Internat. Conf. Peaceful Uses Atomic Energy, 2d, Geneva, 1958, Proc., v. 28, p. 511-516.

Durum, W. H., Heidel, S. G., and Tison, L. T., 1960, World-wide runoff of dissolved solids: Internat. Assoc. Sci. Hydrology, Commission of Surface Waters Pub. 51, p. 618-628.

Feulner, A. J., and Hubble, J. H., 1960, Occurrence of strontium in the surface and ground waters of Champaign County, Ohio: Econ. Geol., v. 55, p. 176-186.

Hevesy, G. von, and Wurstlin, K., 1934, Geochemistry of strontium: Zeitschr. anorg. allg. Chem., v. 216, p. 312-314.

Horr, C. A., 1962, Flame photometric determination of strontium in water: U.S. Geol. Survey Water-Supply Paper 1496-C.

Lohr, E. W., and Love, S. K., 1954, The industrial utility of public water supplies of the United States 1952, pt. 1, States east of the Mississippi River: U.S. Geol. Survey Water-Supply Paper 1299.

Nichols, M. S., and McNall, D. R., 1957, Strontium content of Wisconsin municipal waters: Am. Water Works Assoc. Jour., v. 49, no. 11, p. 1493-1498.

Noll, W., 1934, Geochemistry of strontium: Chemie der Erde, v. 8, p. 507-600.

Odum, H. T., 1951, Strontium in Florida waters, in Black, A. P., and Brown" Eugene, Chemical character of Florida's waters-1951: Florida Board of Conserv., Div. Water Survey and Research, Water Supply and Research Paper 6.

Skougstad, M. W., 1961, Copper-spark method for the spectrochemical determination of strontium in water: U.S. Geol. Survey Water-Supply Paper 1496-B.

Turekian, K. K., and Kulp, J. L., 1956, Geochemistry of strontium: Geochim. et Cosmochim. Acta, v. 10, p. 245-296. 


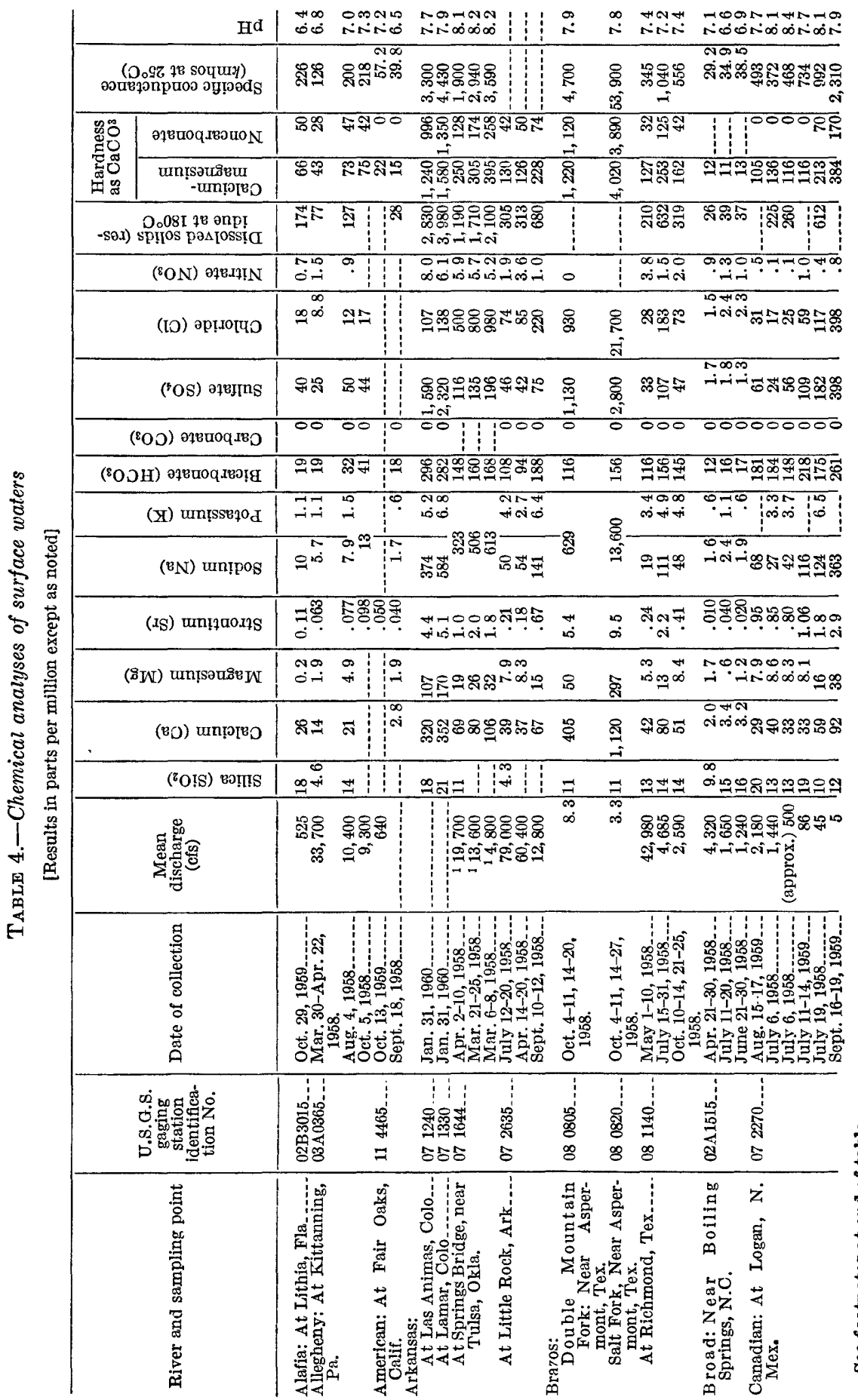




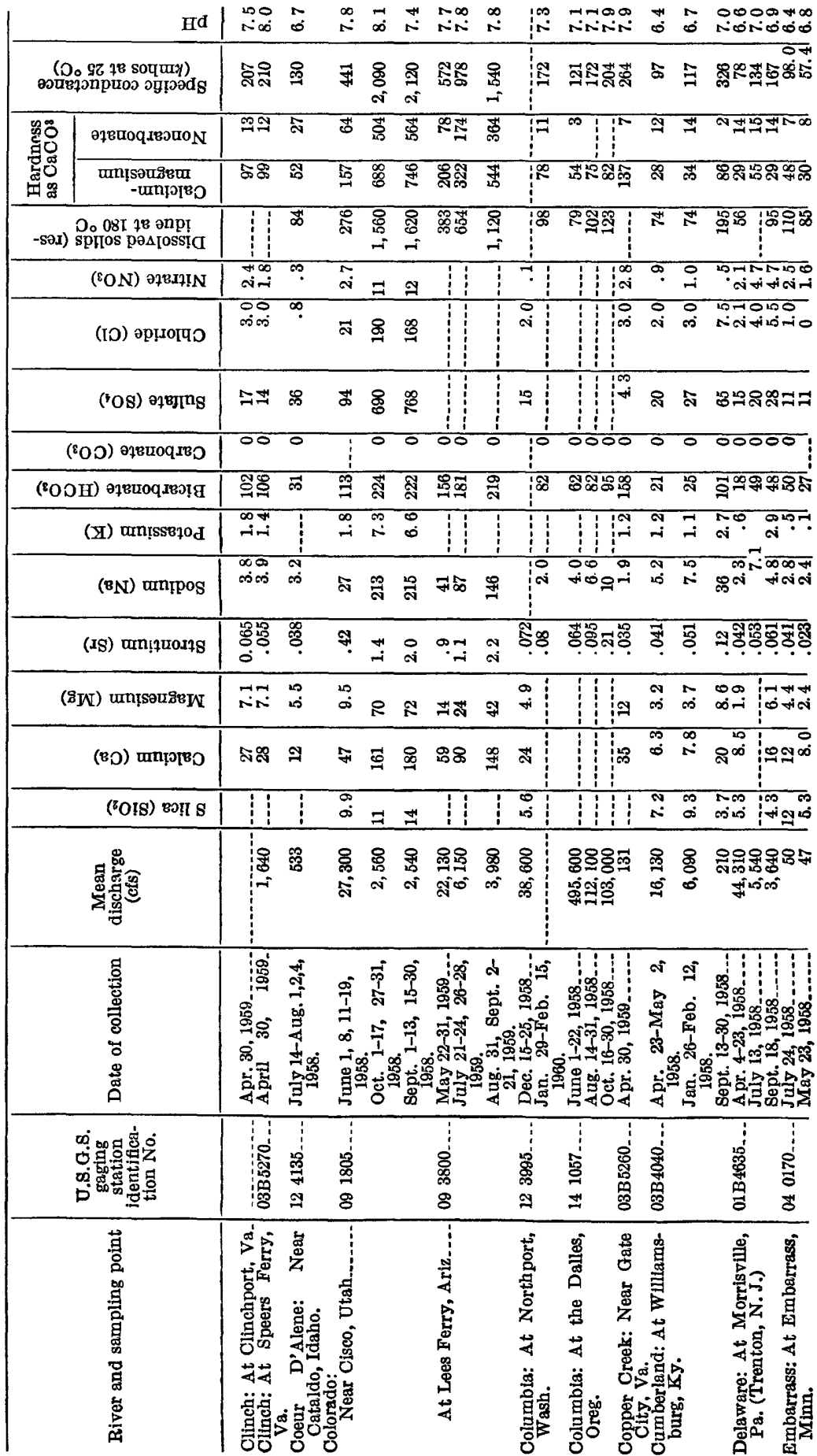


I L

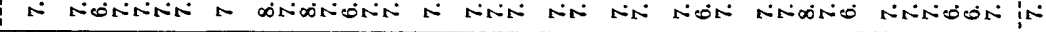

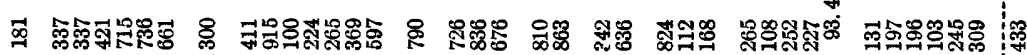

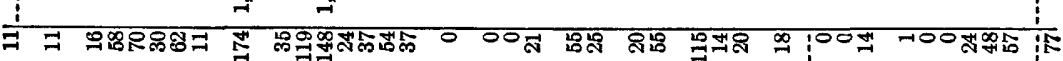

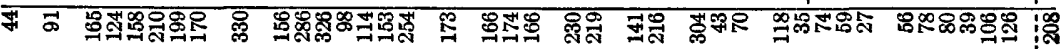

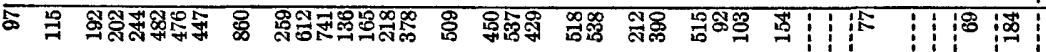

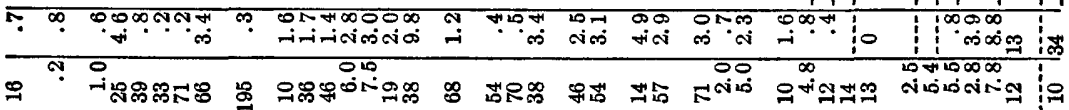

+

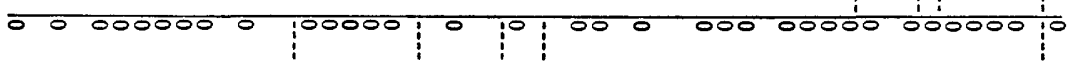

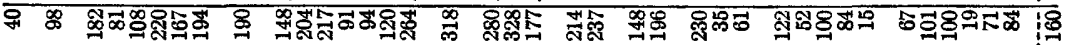

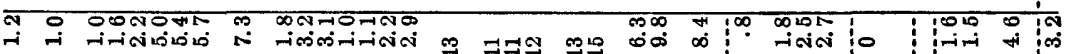

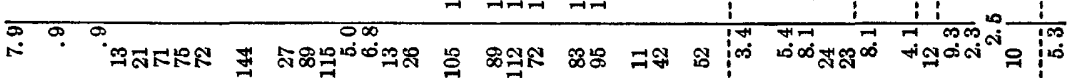

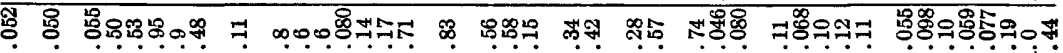

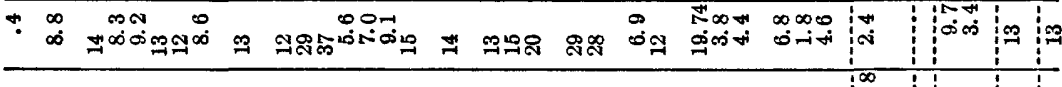

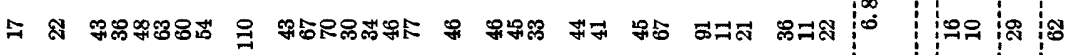

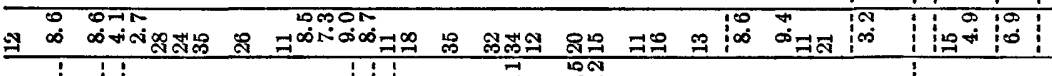

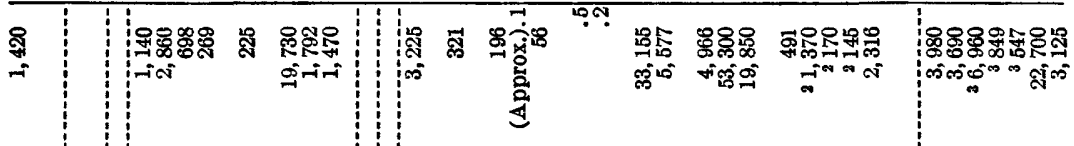

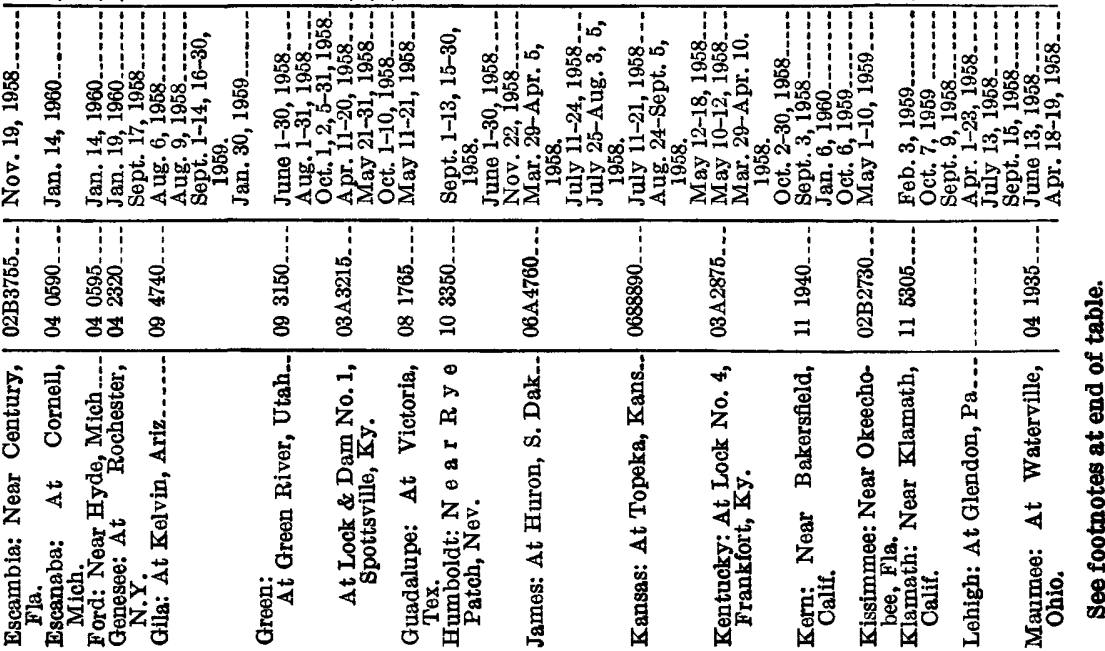




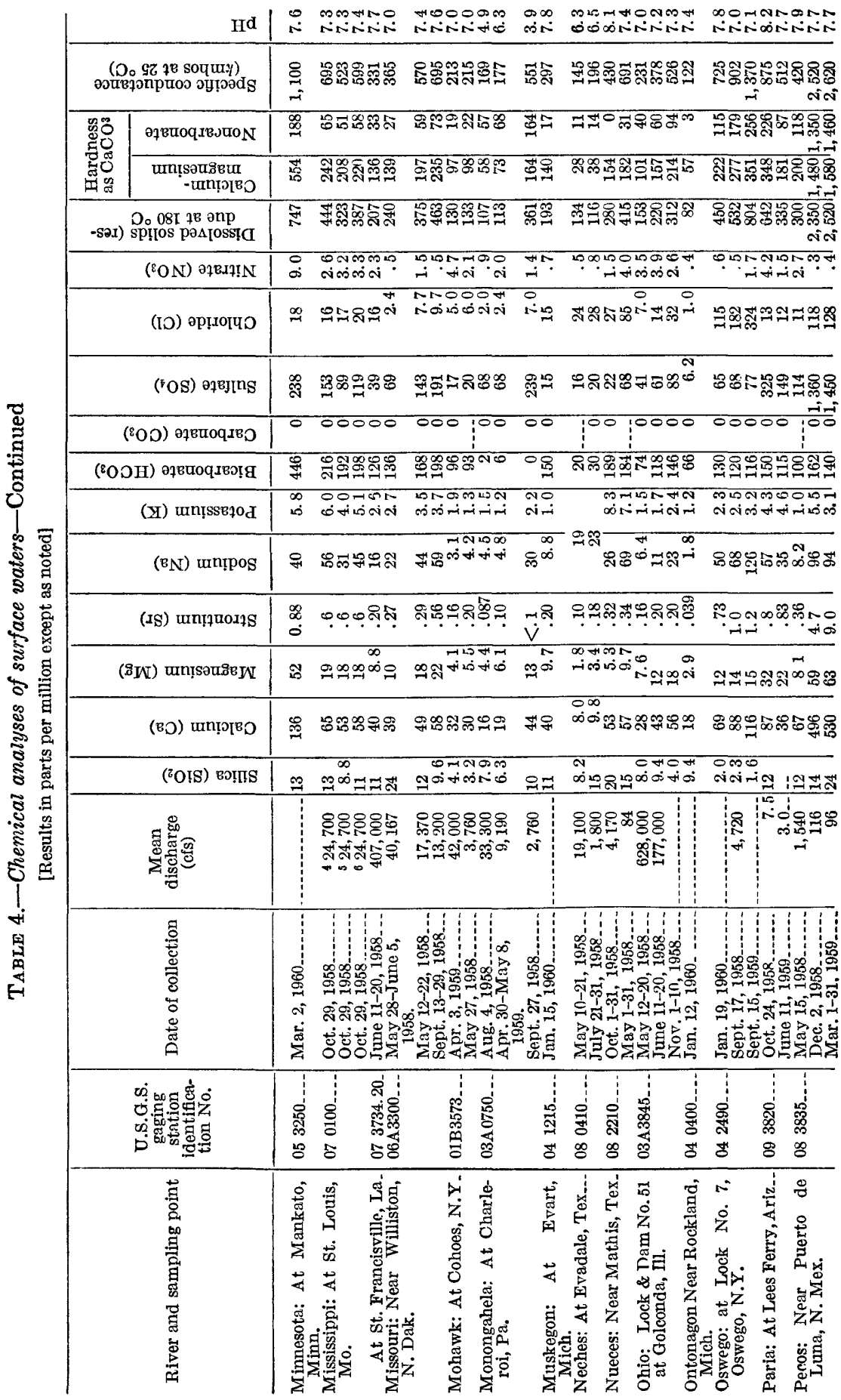




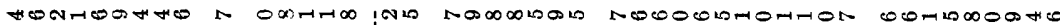

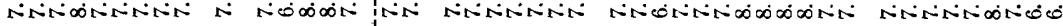

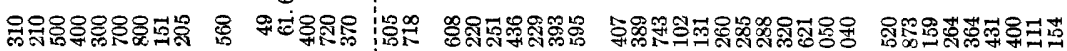

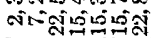

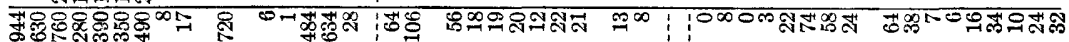
-inciciviti

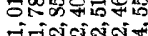

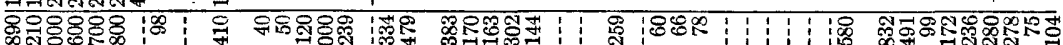

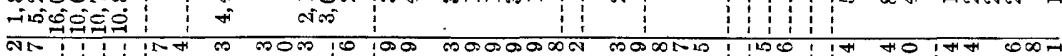

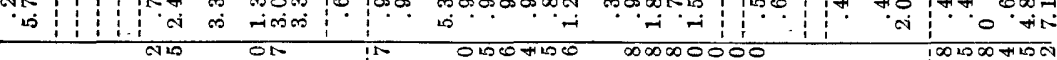

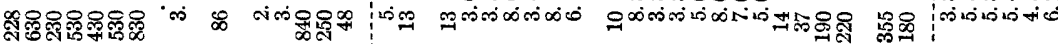

नinfifít

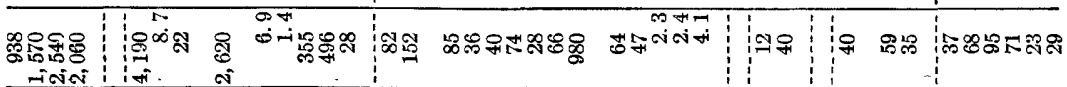

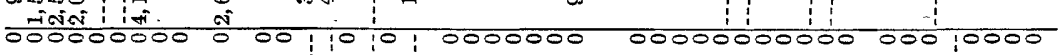
æ:

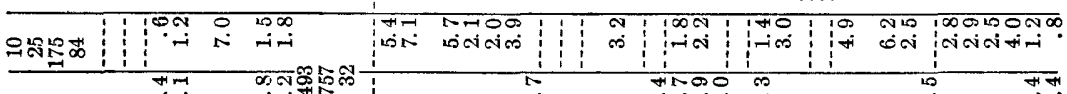

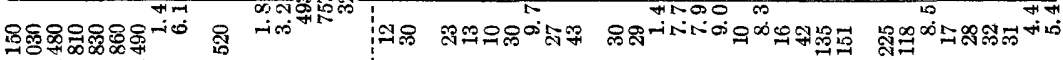
inicióntion

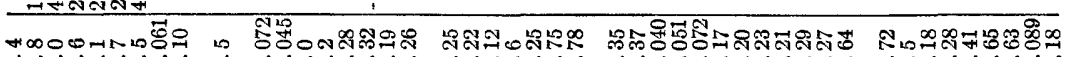

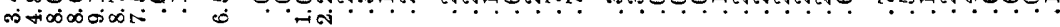

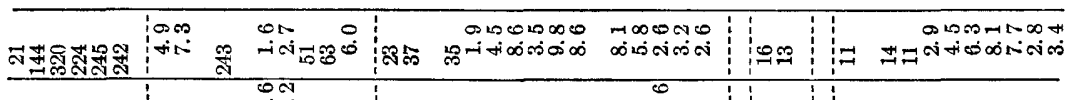

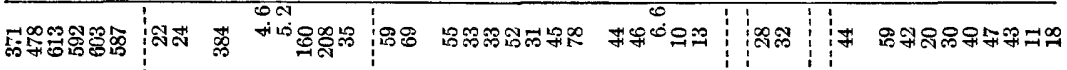
2mำ

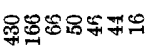

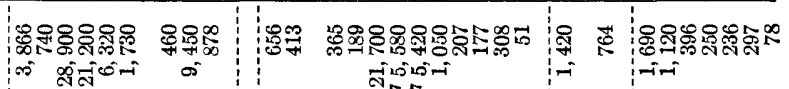

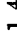

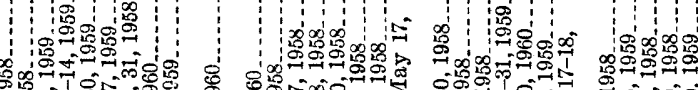

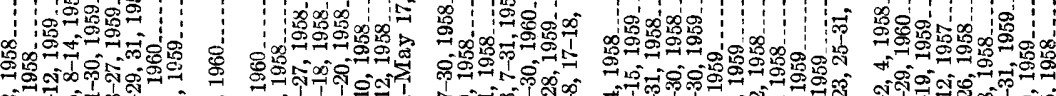

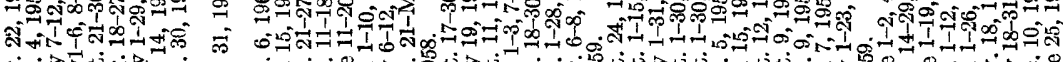

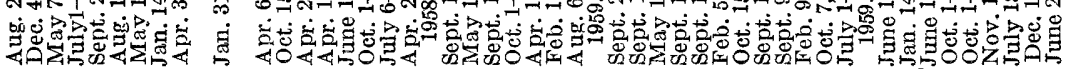

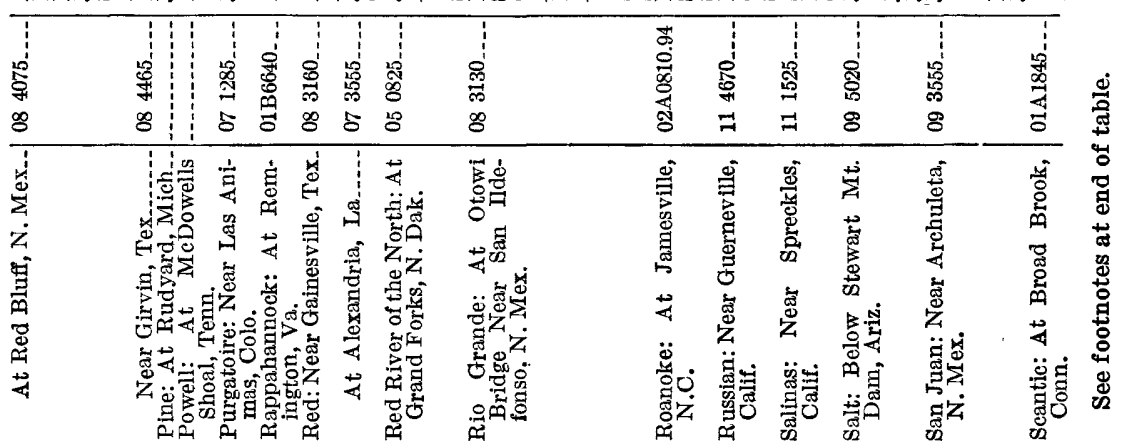




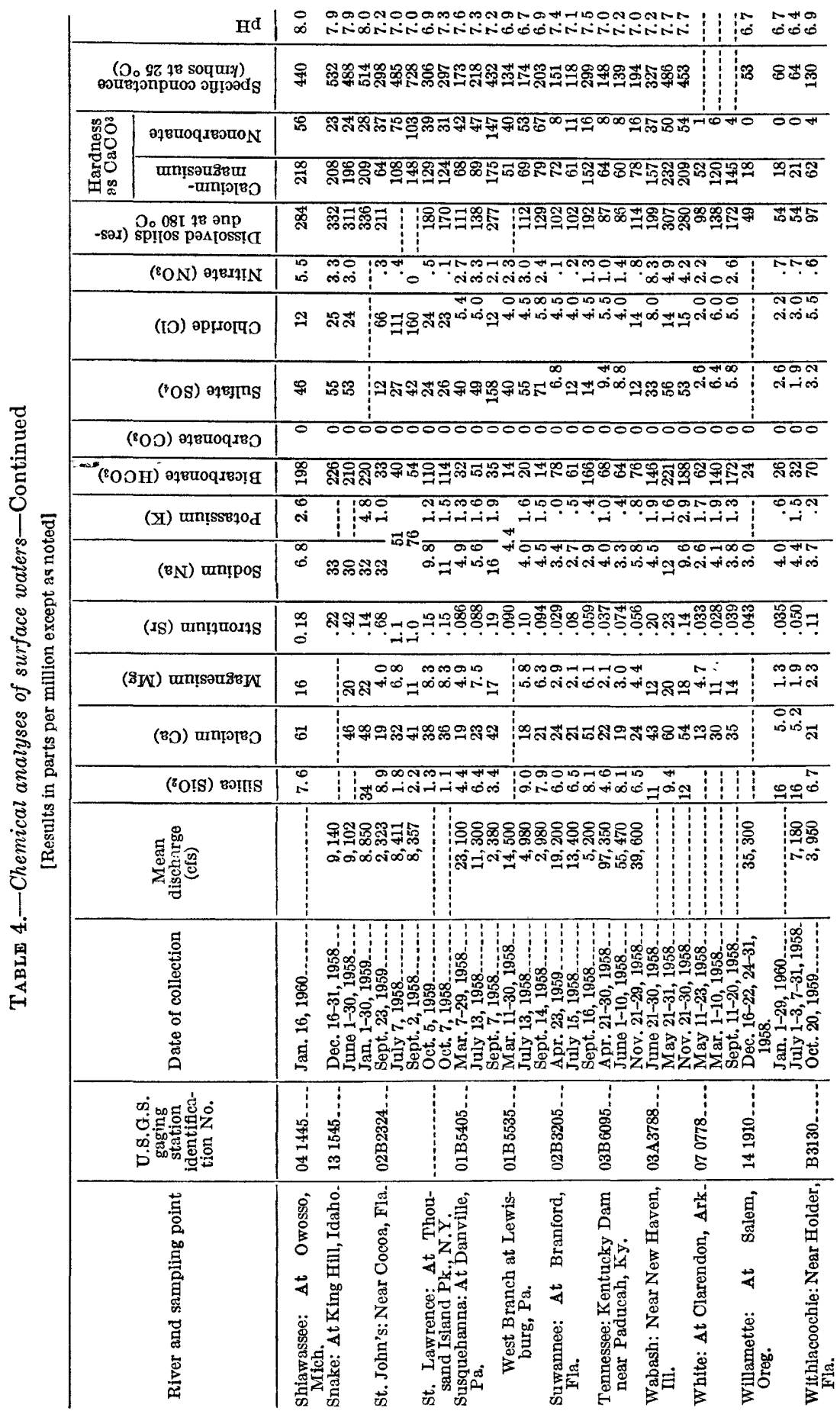




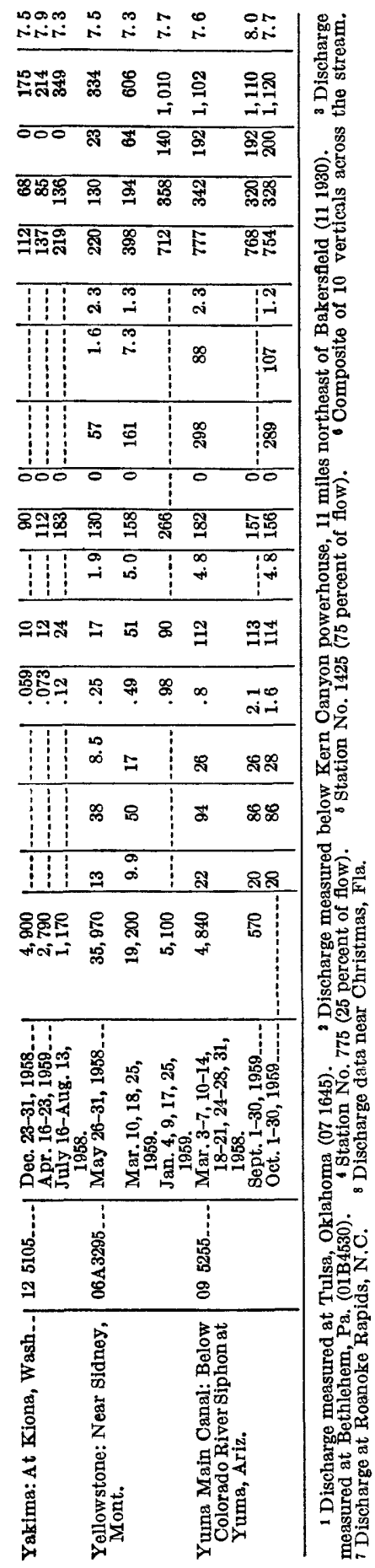




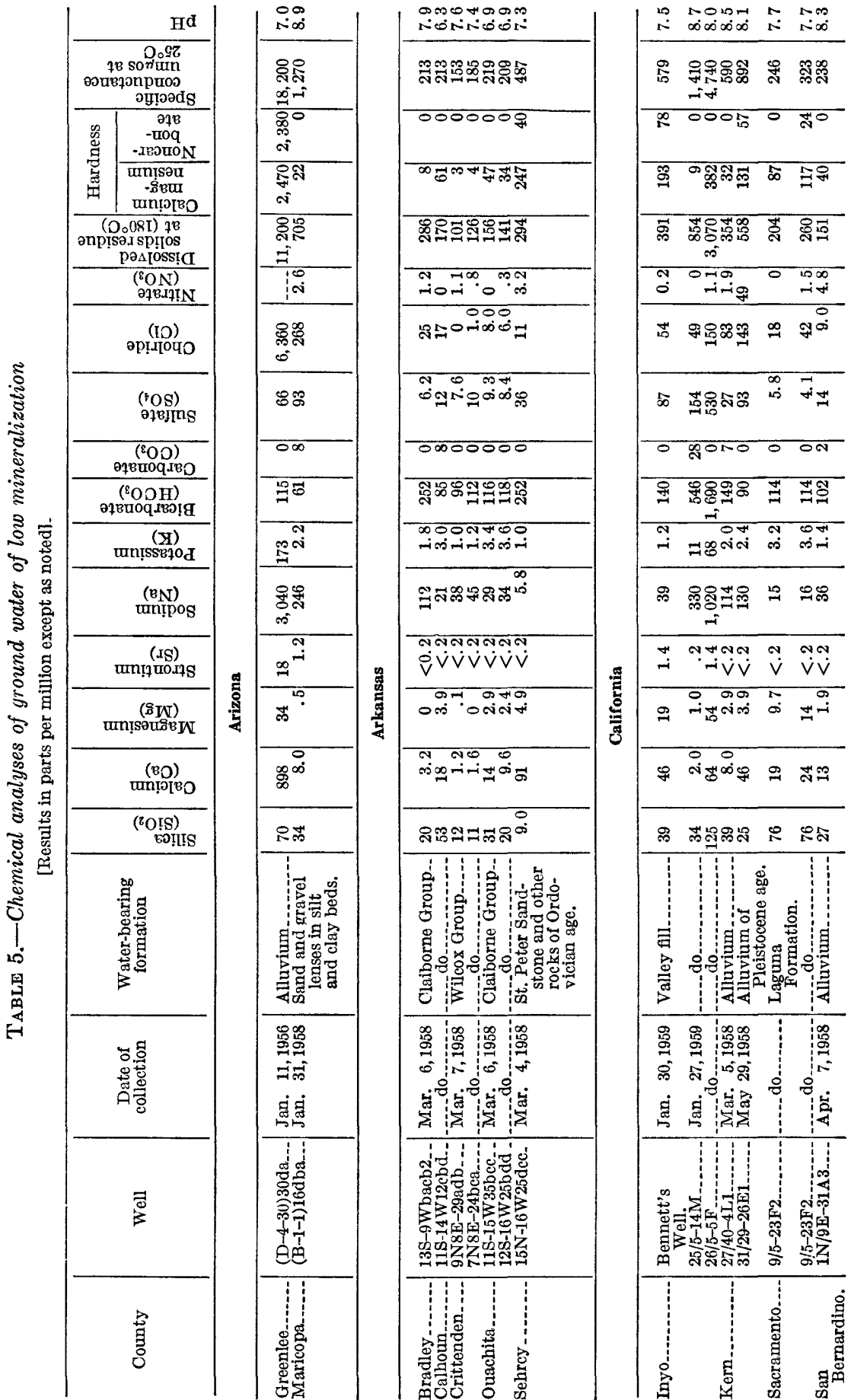




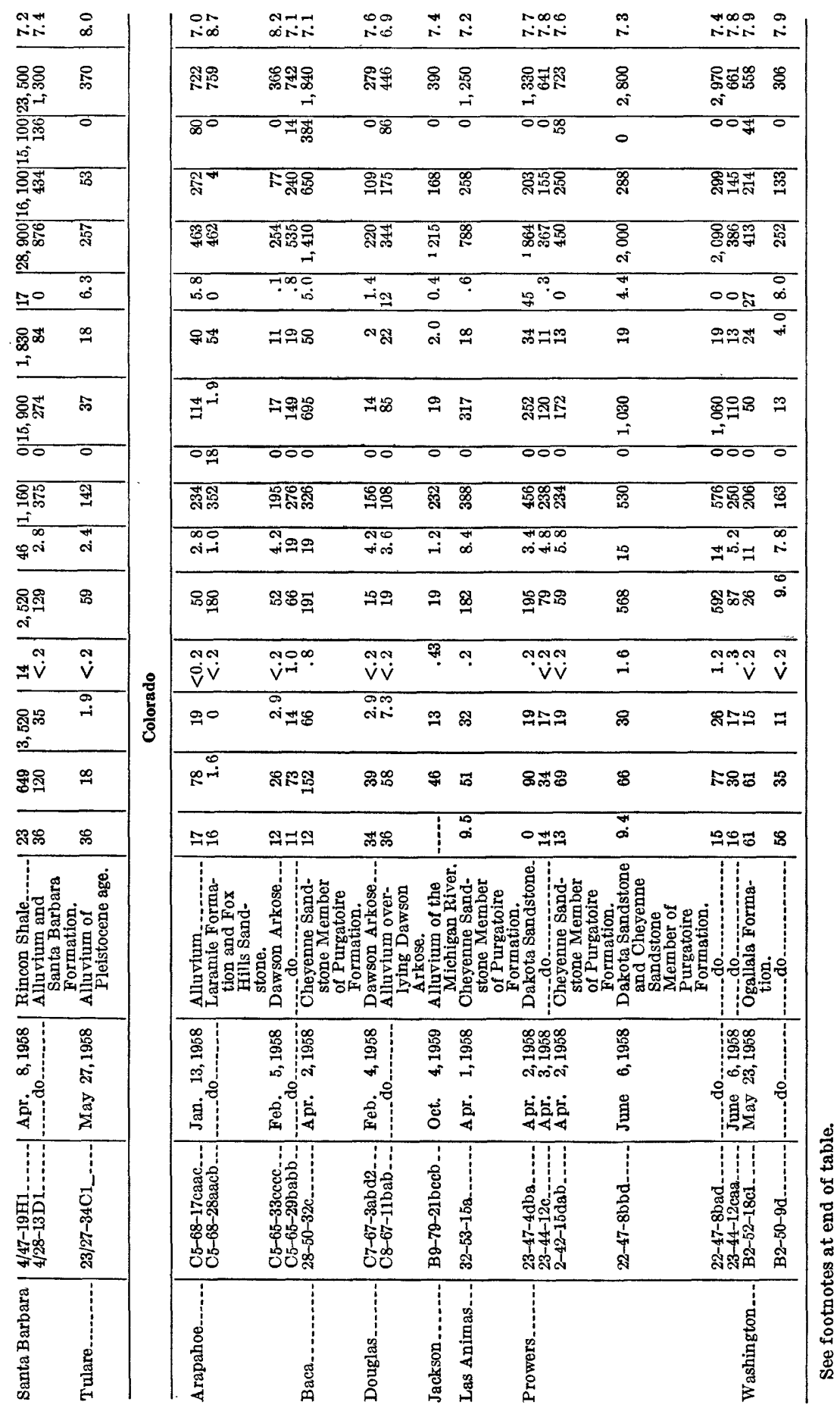




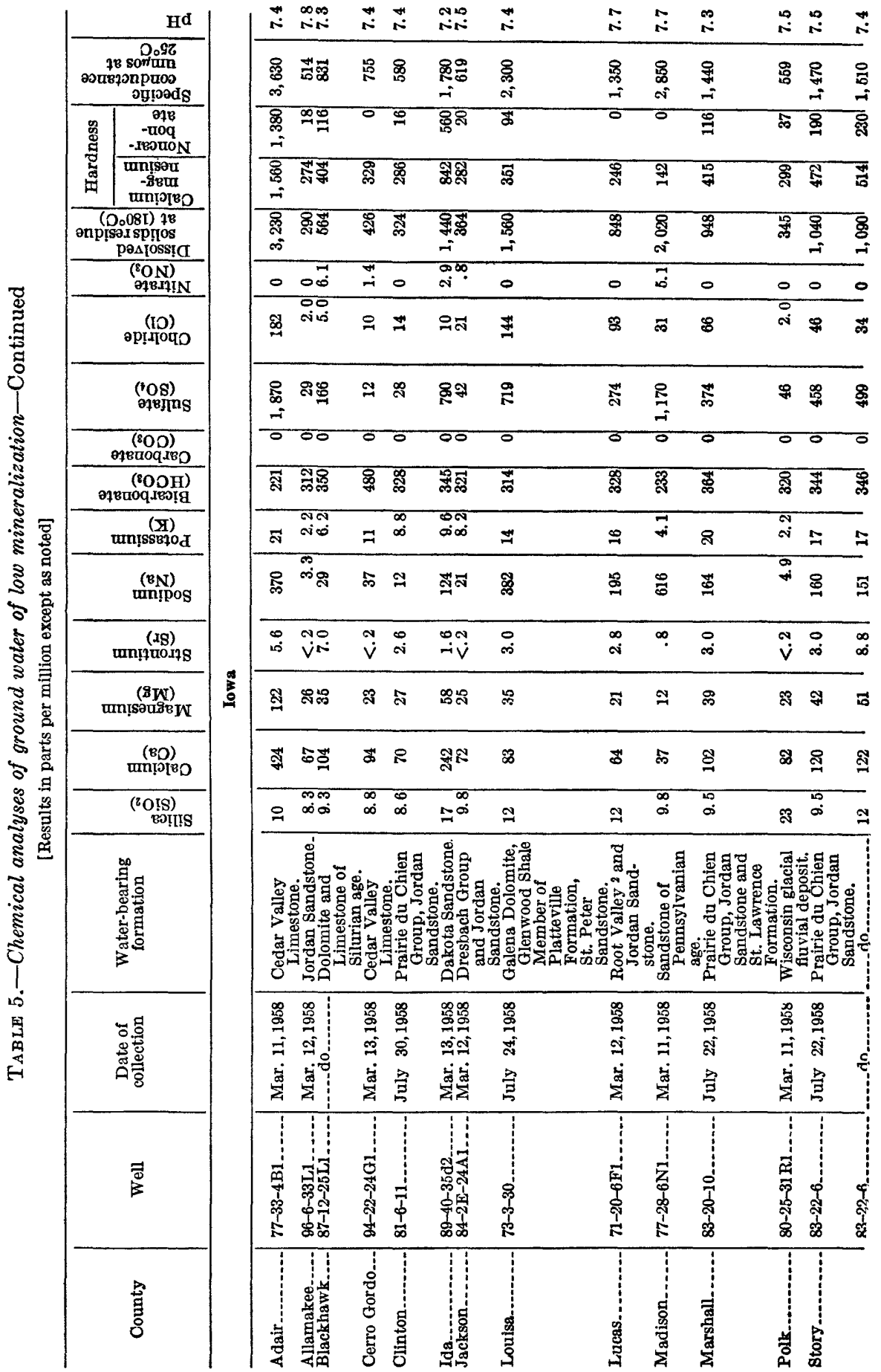




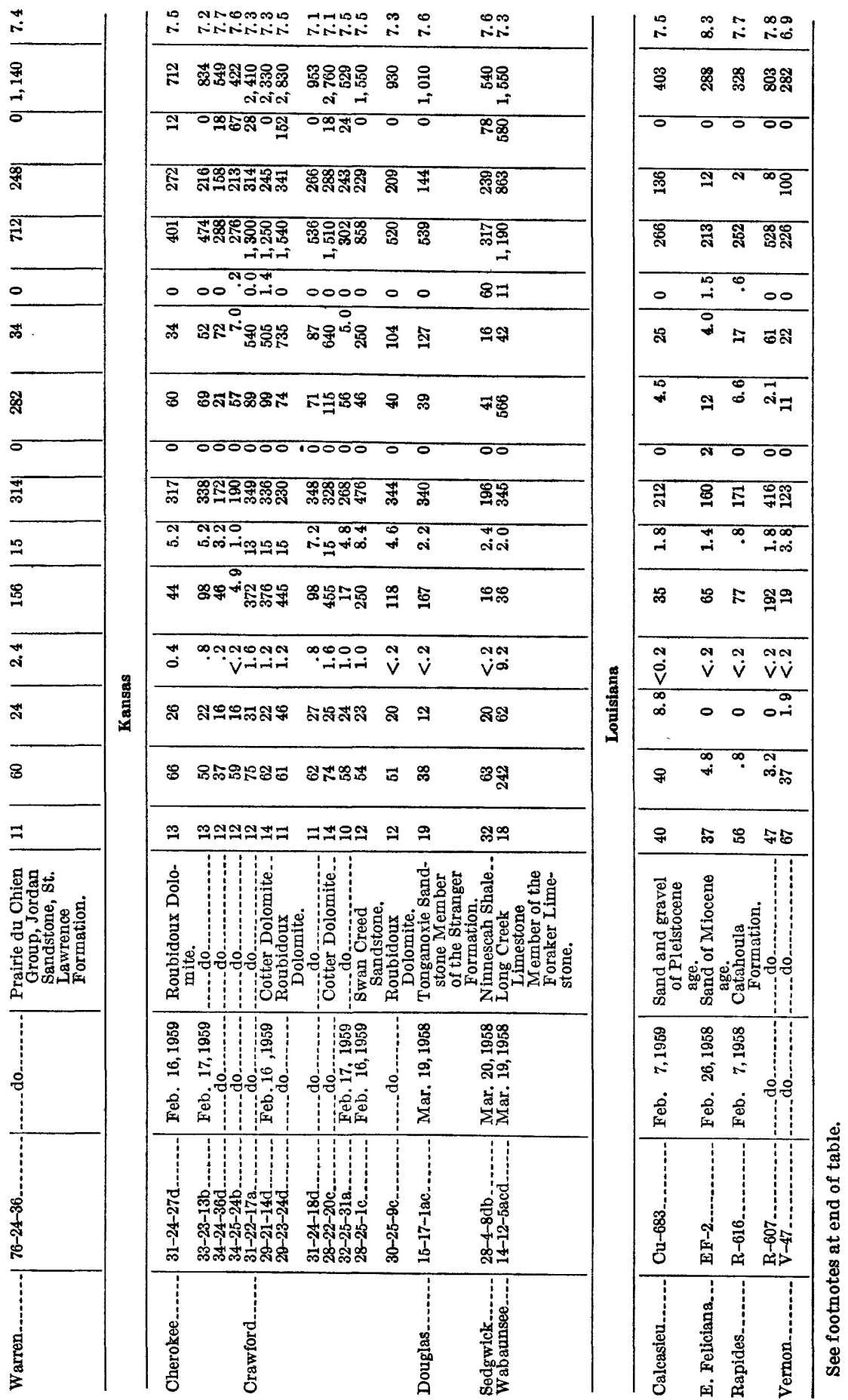




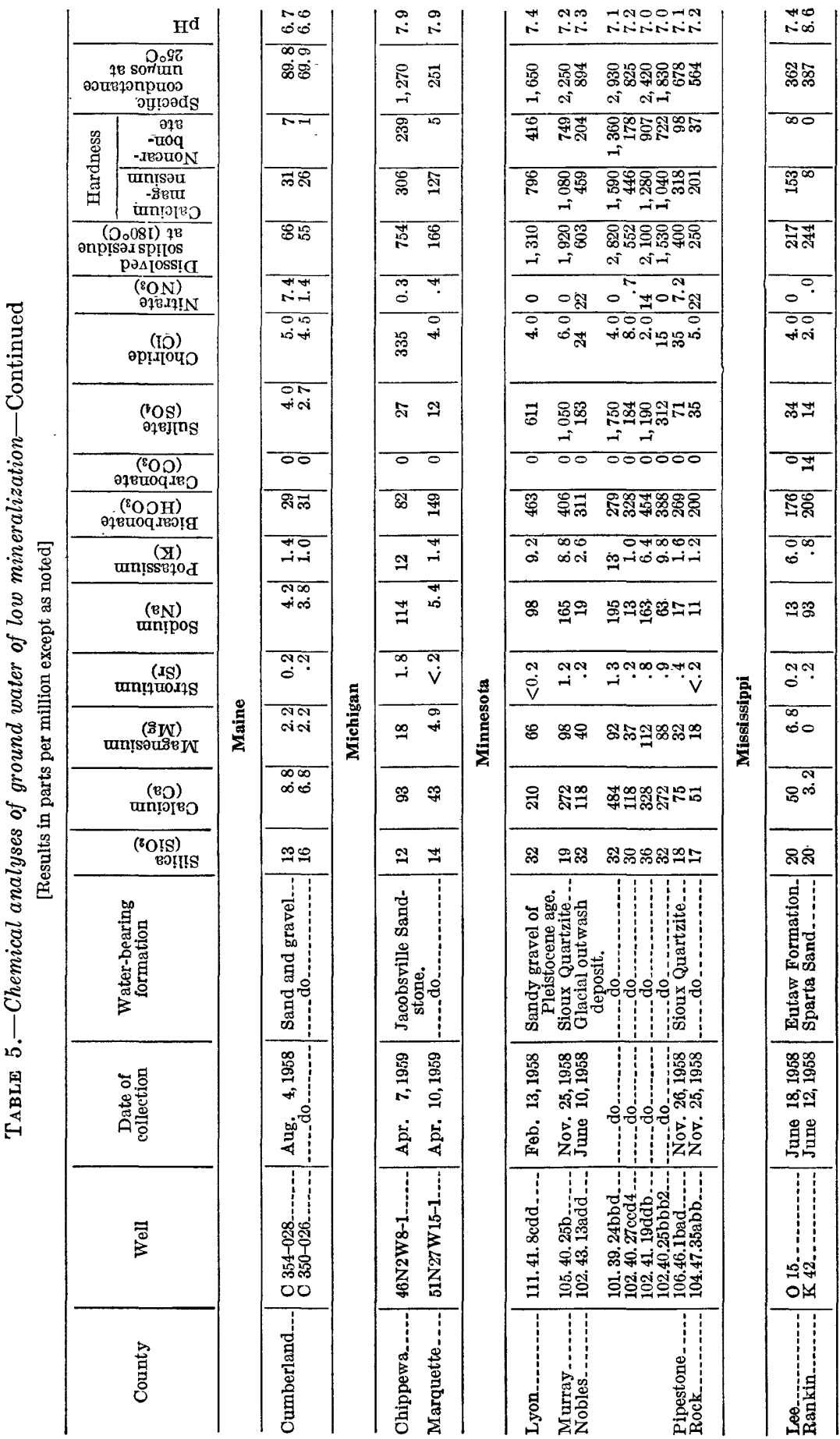




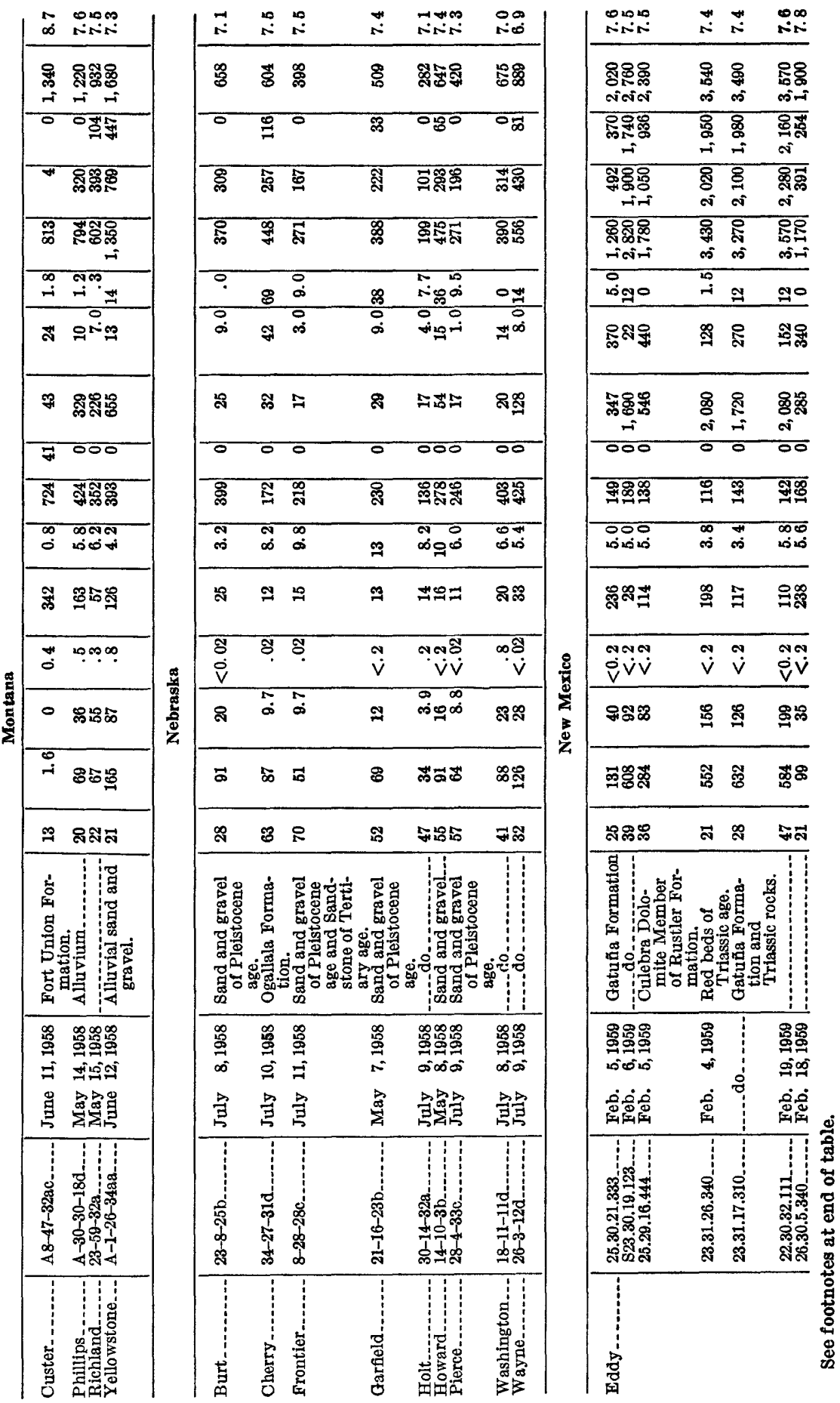




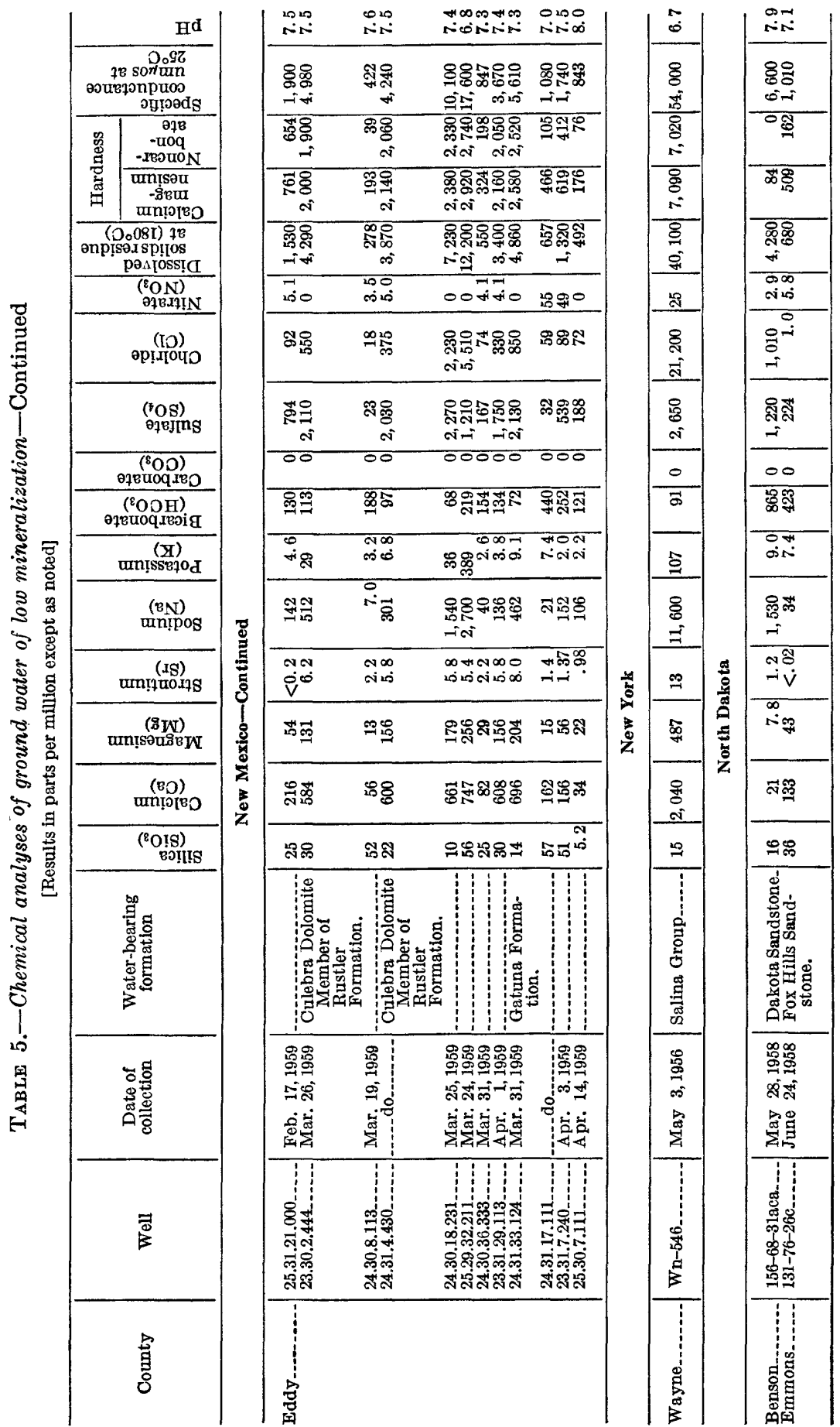




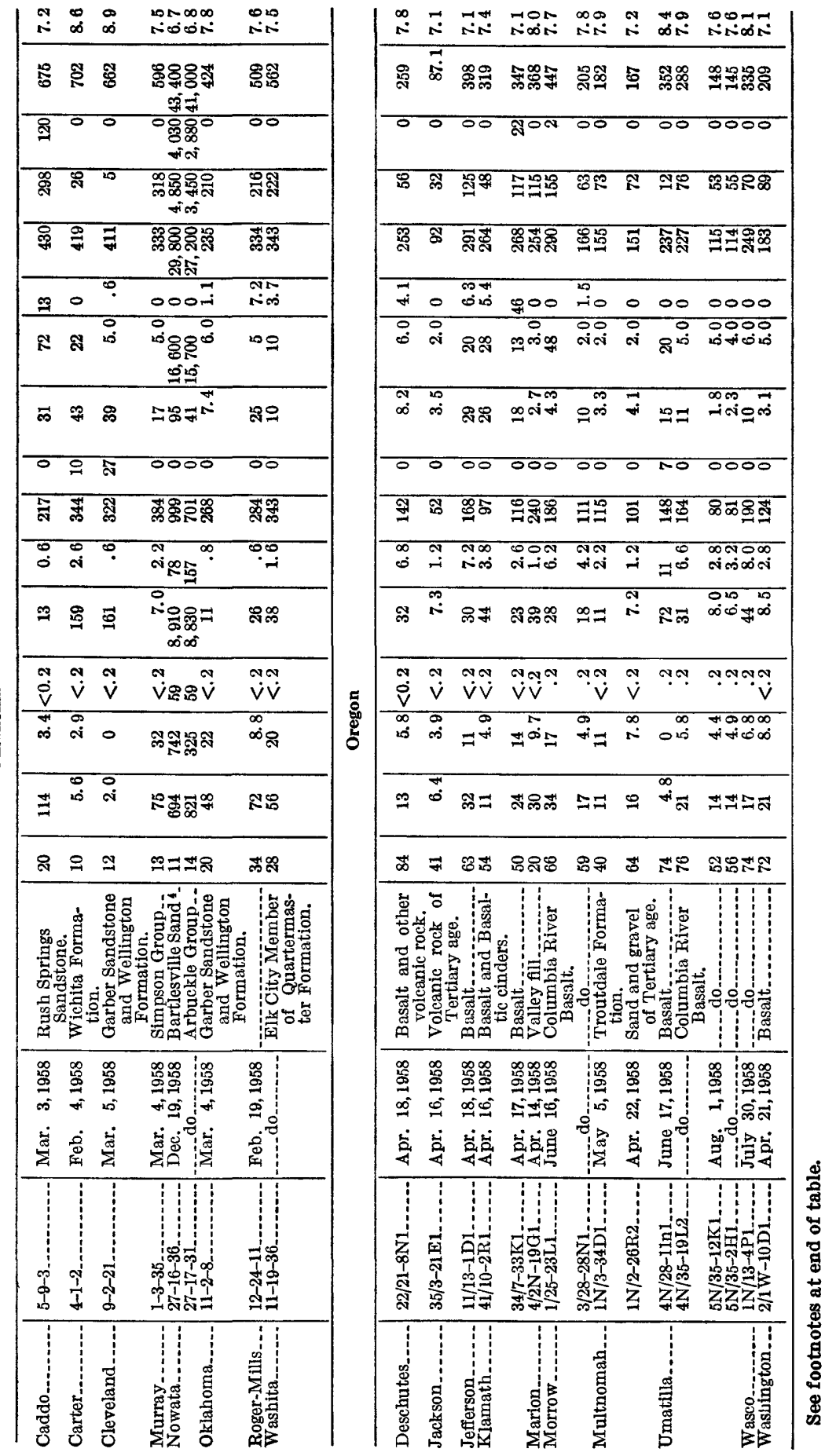




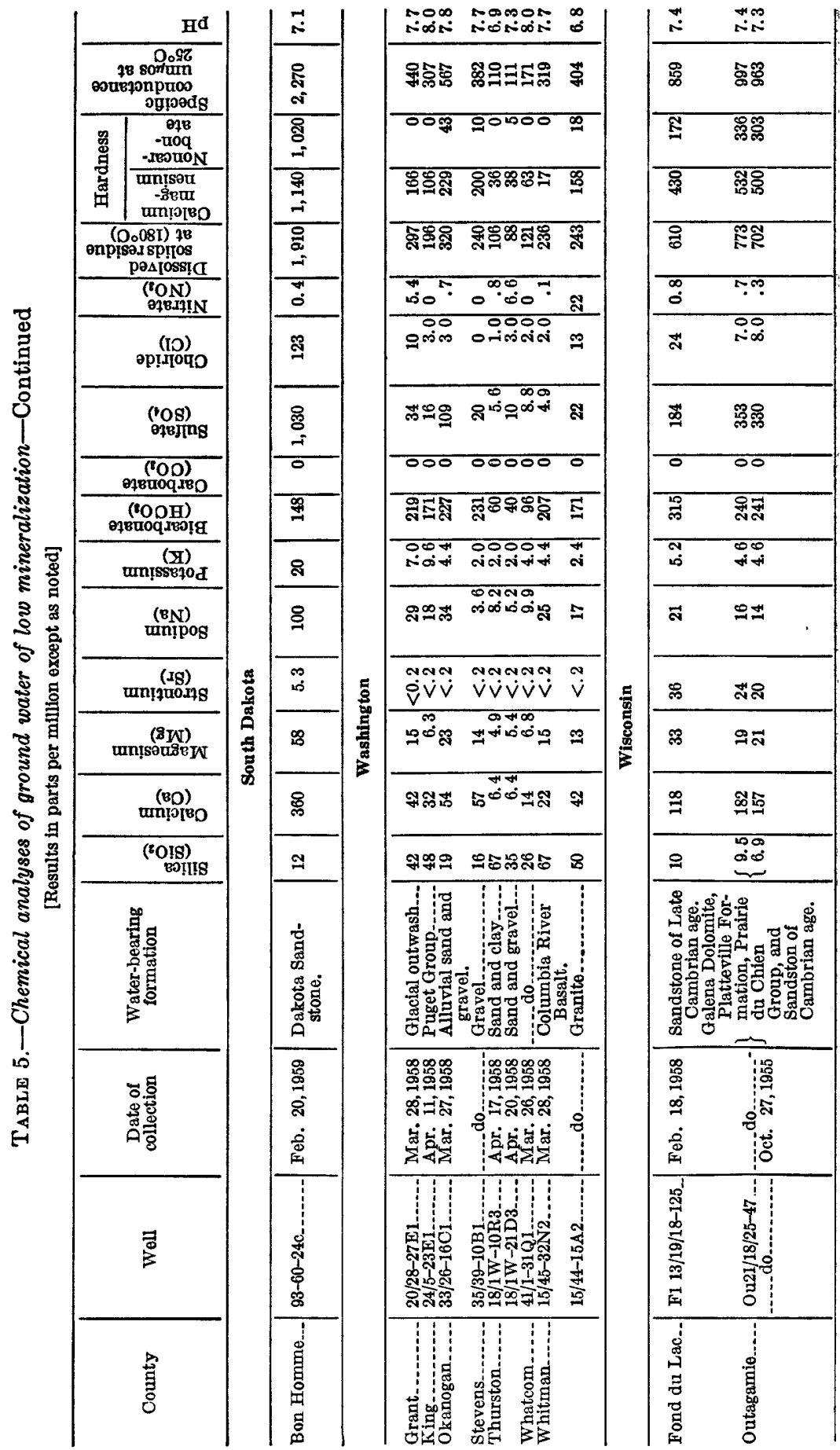




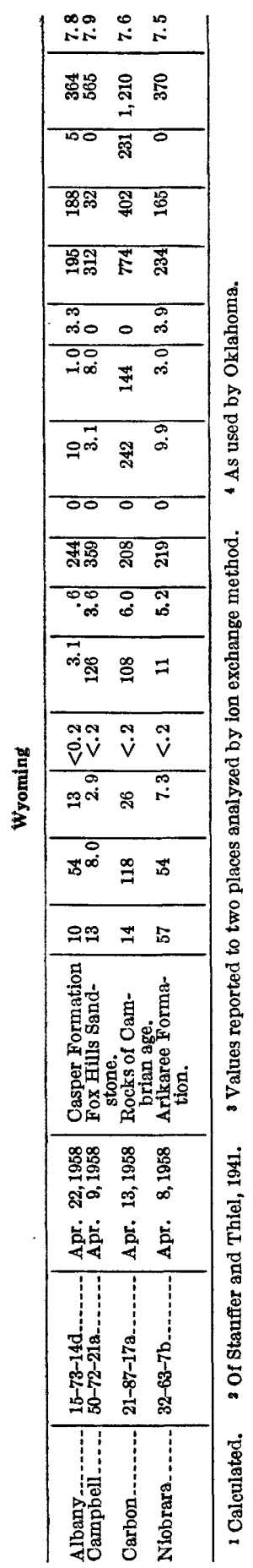




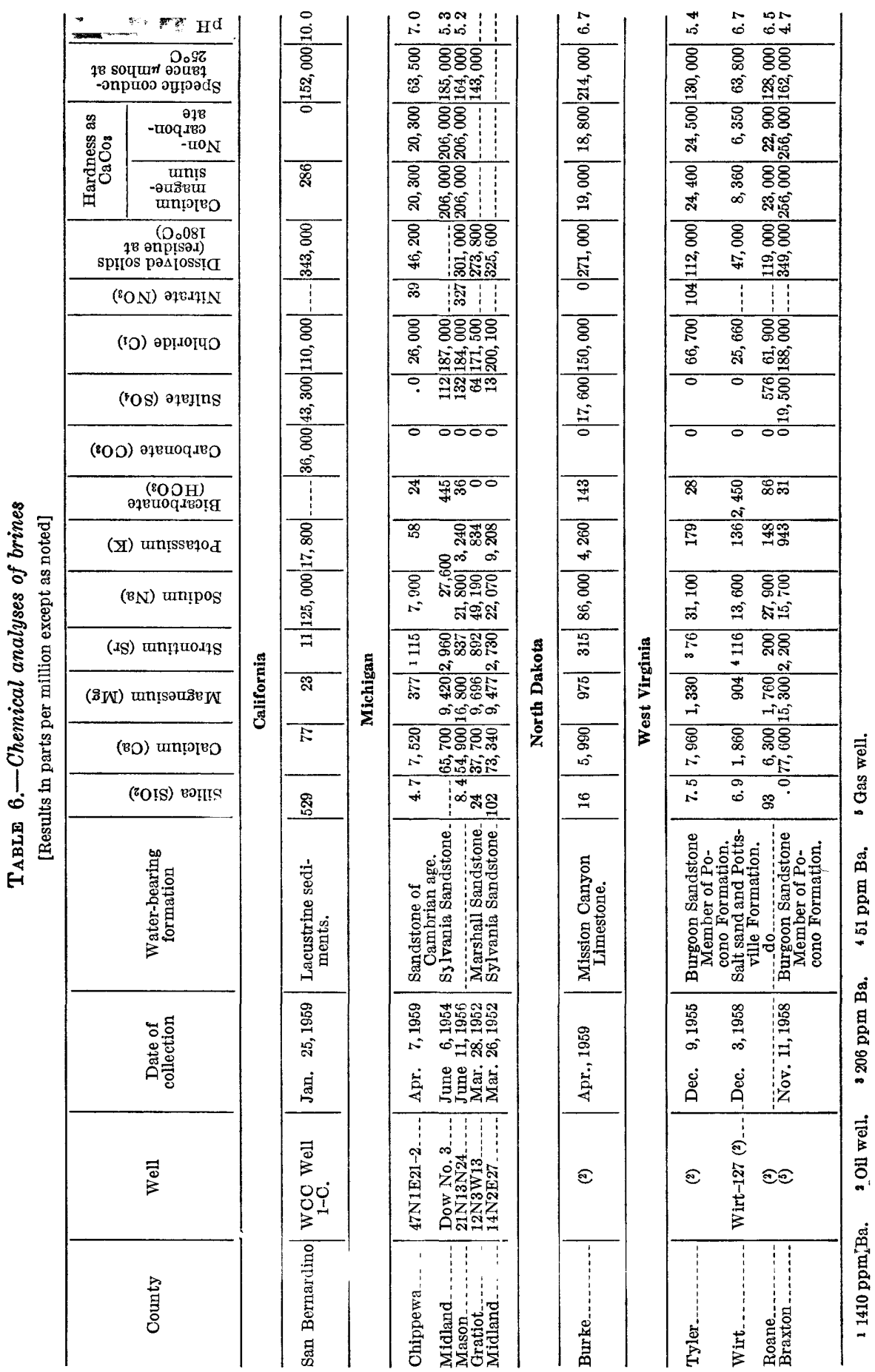




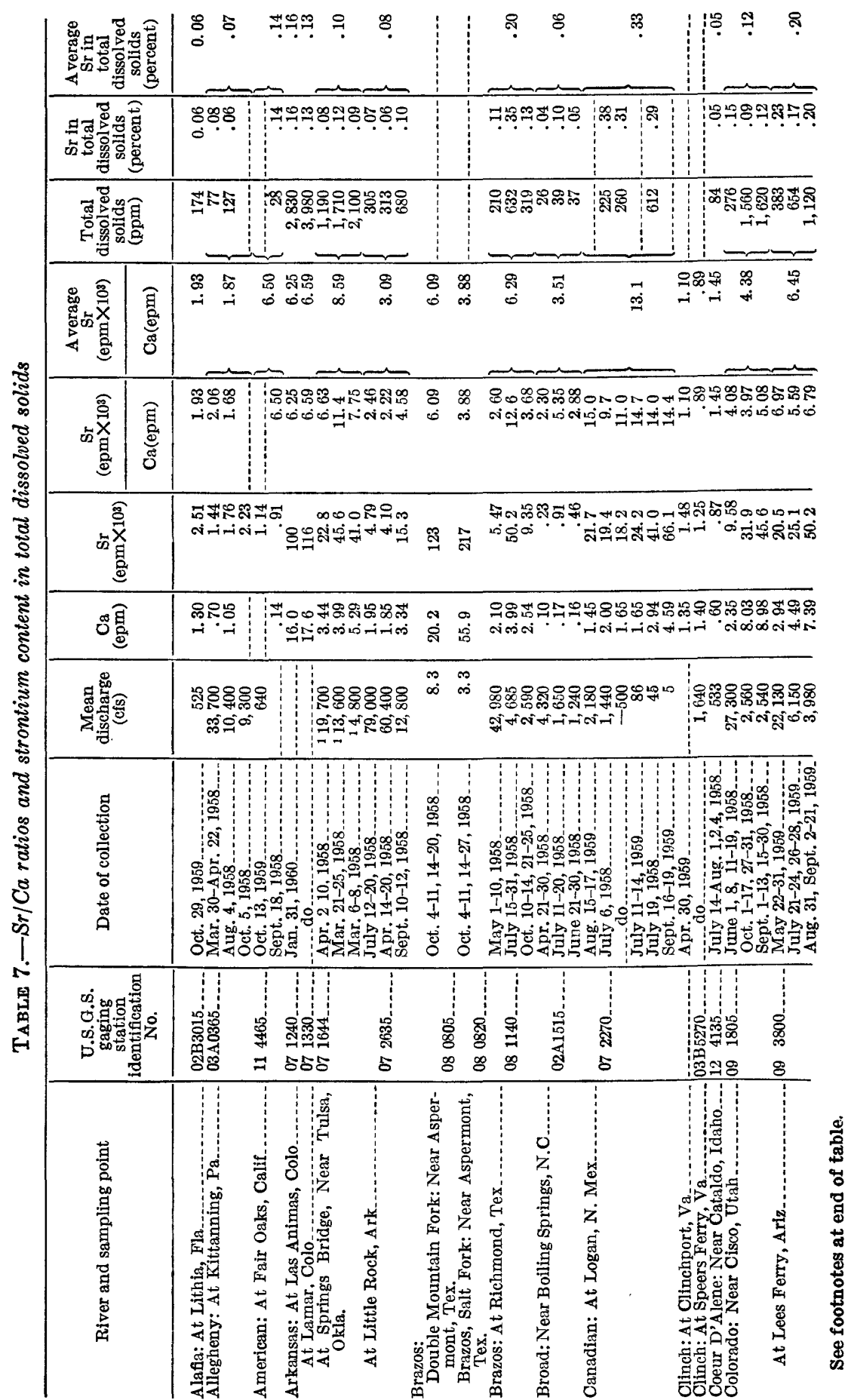




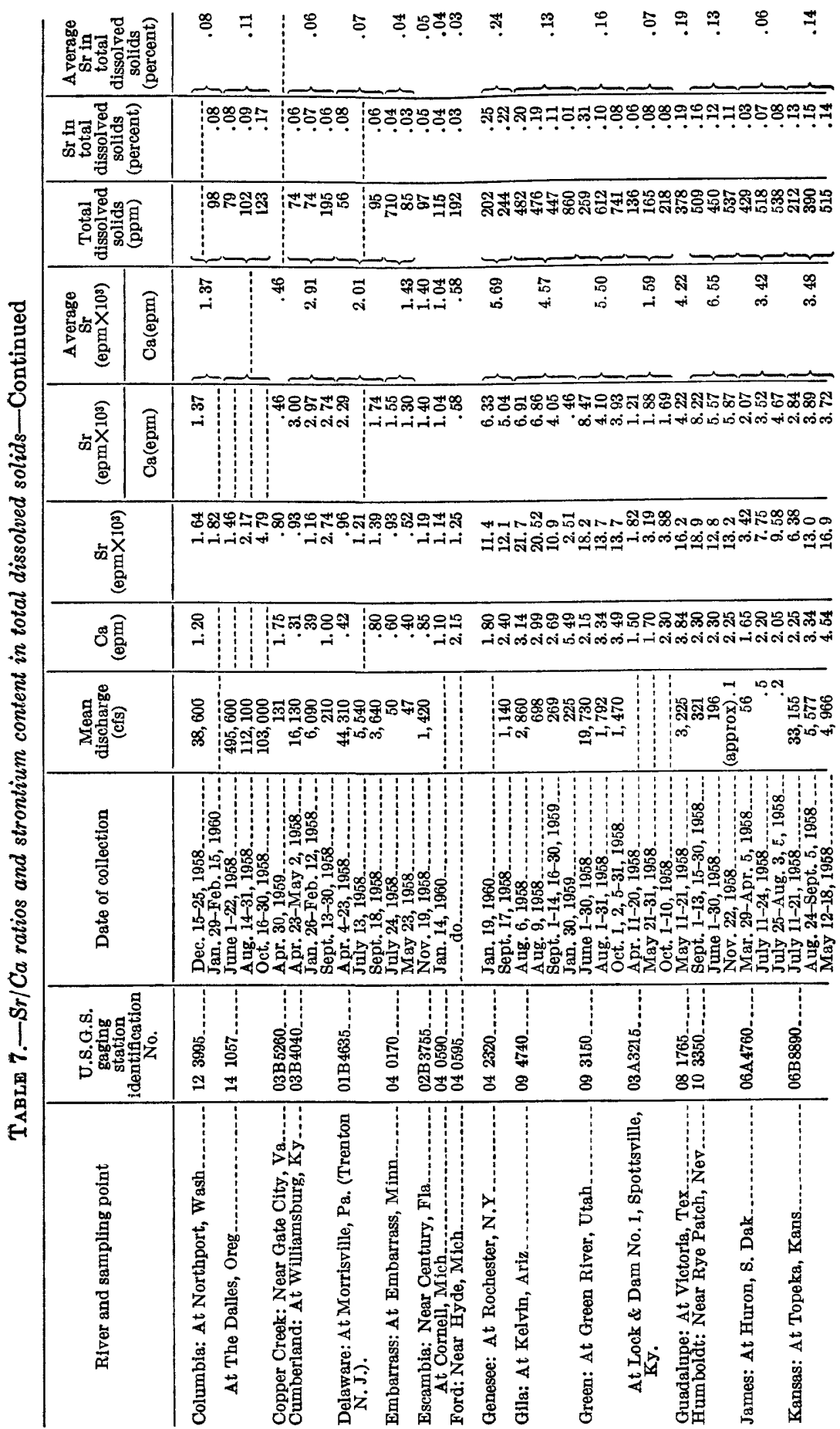



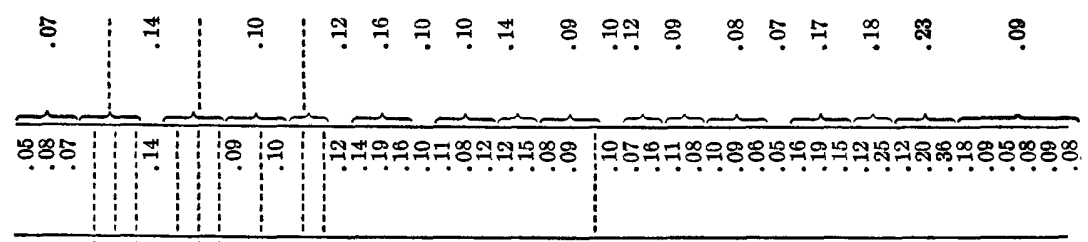

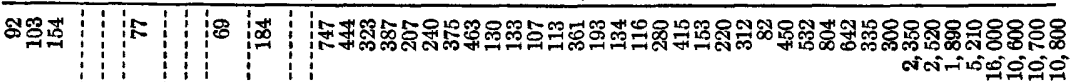

\begin{tabular}{|c|c|c|c|c|c|c|c|c|c|c|c|c|c|c|c|c|c|}
\hline$\stackrel{8}{\stackrel{8}{\oplus}}$ & $\stackrel{29}{\text { ลे }}$ & $\stackrel{\infty}{\infty}$ & $\begin{array}{l}\infty \\
\infty\end{array}$ & $\begin{array}{l}H^{\prime} \\
\text { i }\end{array}$ & $\begin{array}{l}\vec{N} \& \\
\text { ஸे }\end{array}$ & $\begin{array}{l}\text { 尺 } \\
+ \\
+\end{array}$ & \begin{tabular}{l}
$\infty$ \\
\multirow{N}{N}{} \\
on
\end{tabular} & $\underset{\Re}{\mathscr{q}}$ & $\begin{array}{l}8 \\
\text { ஸे }\end{array}$ & $\begin{array}{l}\underset{5}{\text { s }} \\
\text { i }\end{array}$ & $\begin{array}{l}\text { 足 } \\
\text { c゙ } \\
\text { c }\end{array}$ & 点 & $\begin{array}{l}\underset{7}{*} \\
\text { ơ }\end{array}$ & ஜ্. & $\stackrel{8}{8}$ & $r$ & $\begin{array}{l}\bar{\infty} \\
+\end{array}$ \\
\hline
\end{tabular}

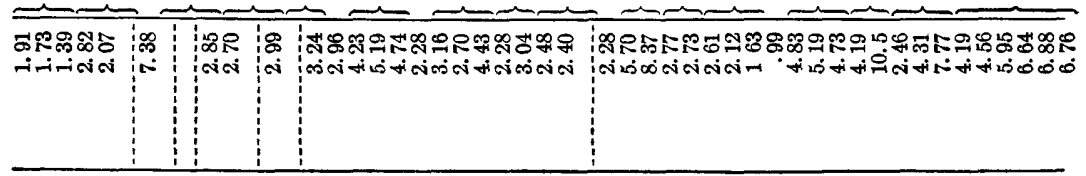

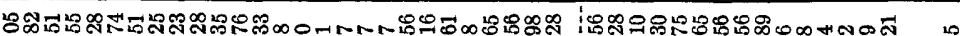

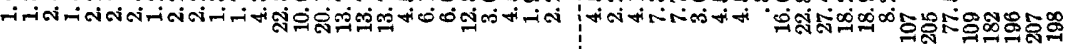

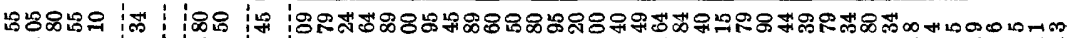

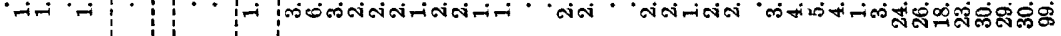

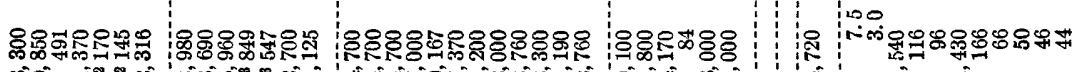

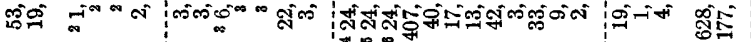

\begin{tabular}{|c|c|c|c|c|c|c|c|c|c|c|c|c|c|}
\hline 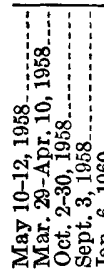 & 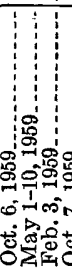 & & 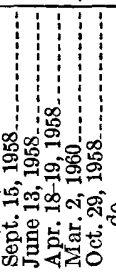 & 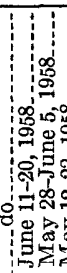 & 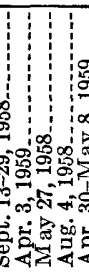 & 05 & & $=$ & 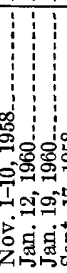 & 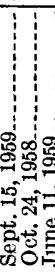 & & 3 & 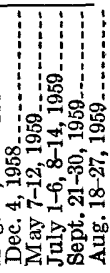 \\
\hline $\begin{array}{l}\text { 용 } \\
\Rightarrow\end{array}$ & 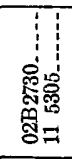 & & 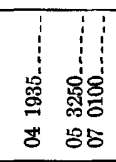 & 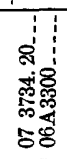 & 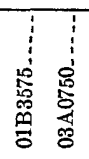 & 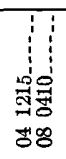 & $\begin{array}{l}\text { 여ํ } \\
\text { สิ } \\
\text { g }\end{array}$ & 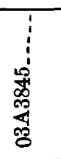 & 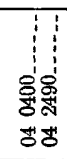 & $\begin{array}{l}\text { वें } \\
\text { o. } \\
\varnothing \\
\varnothing\end{array}$ & 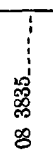 & 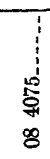 & \\
\hline 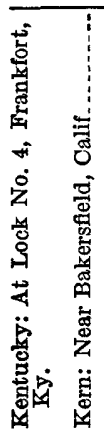 & 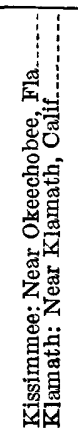 & 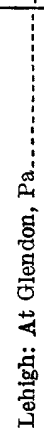 & 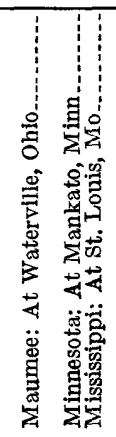 & 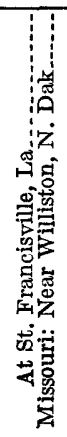 & 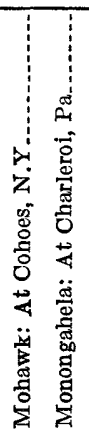 & 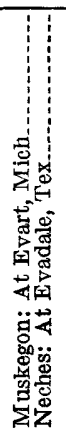 & 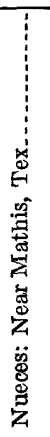 & 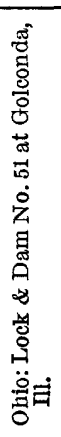 & 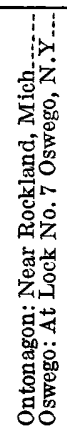 & 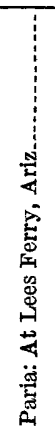 & 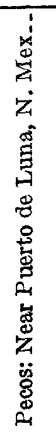 & 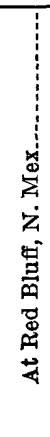 & \\
\hline
\end{tabular}




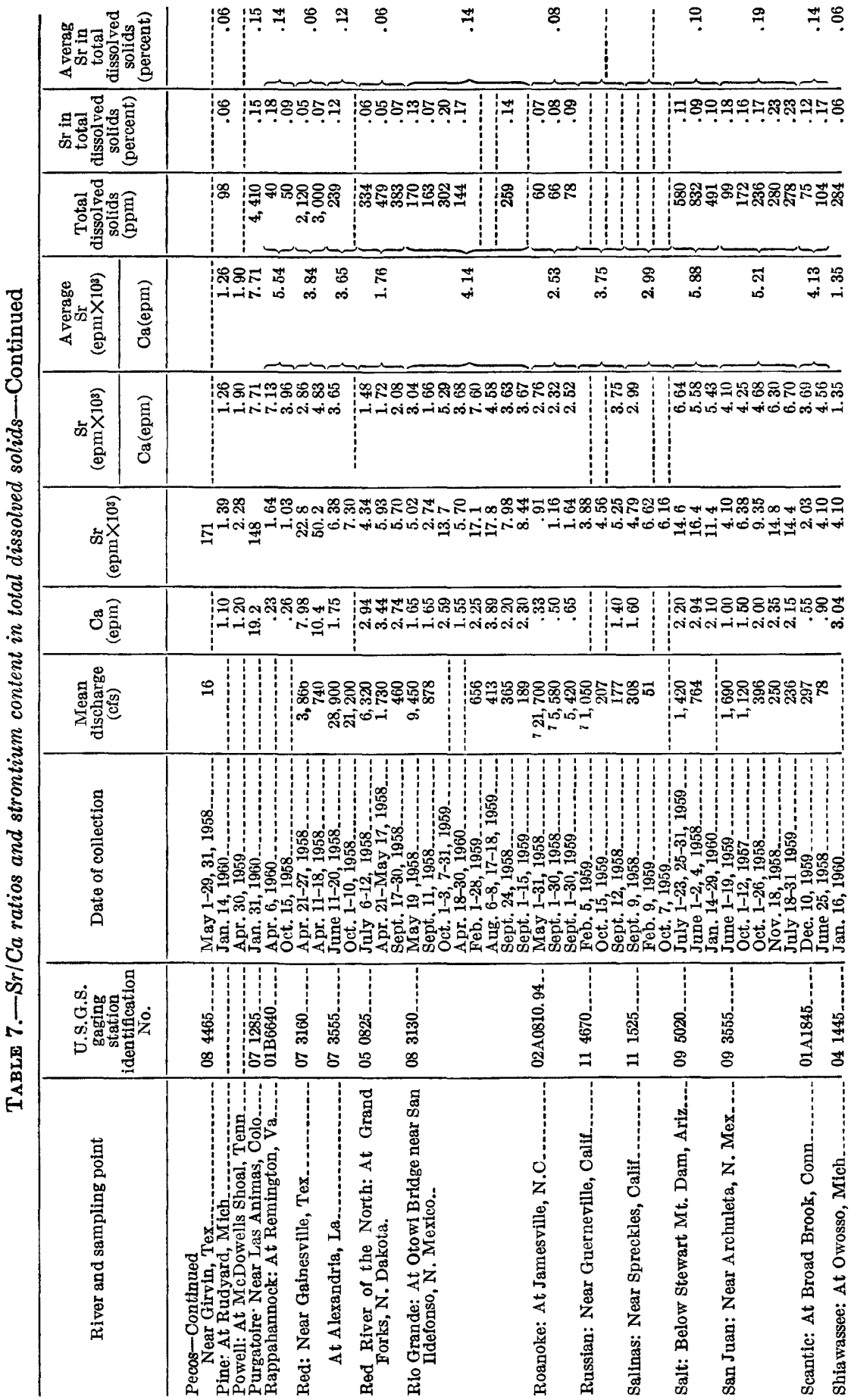




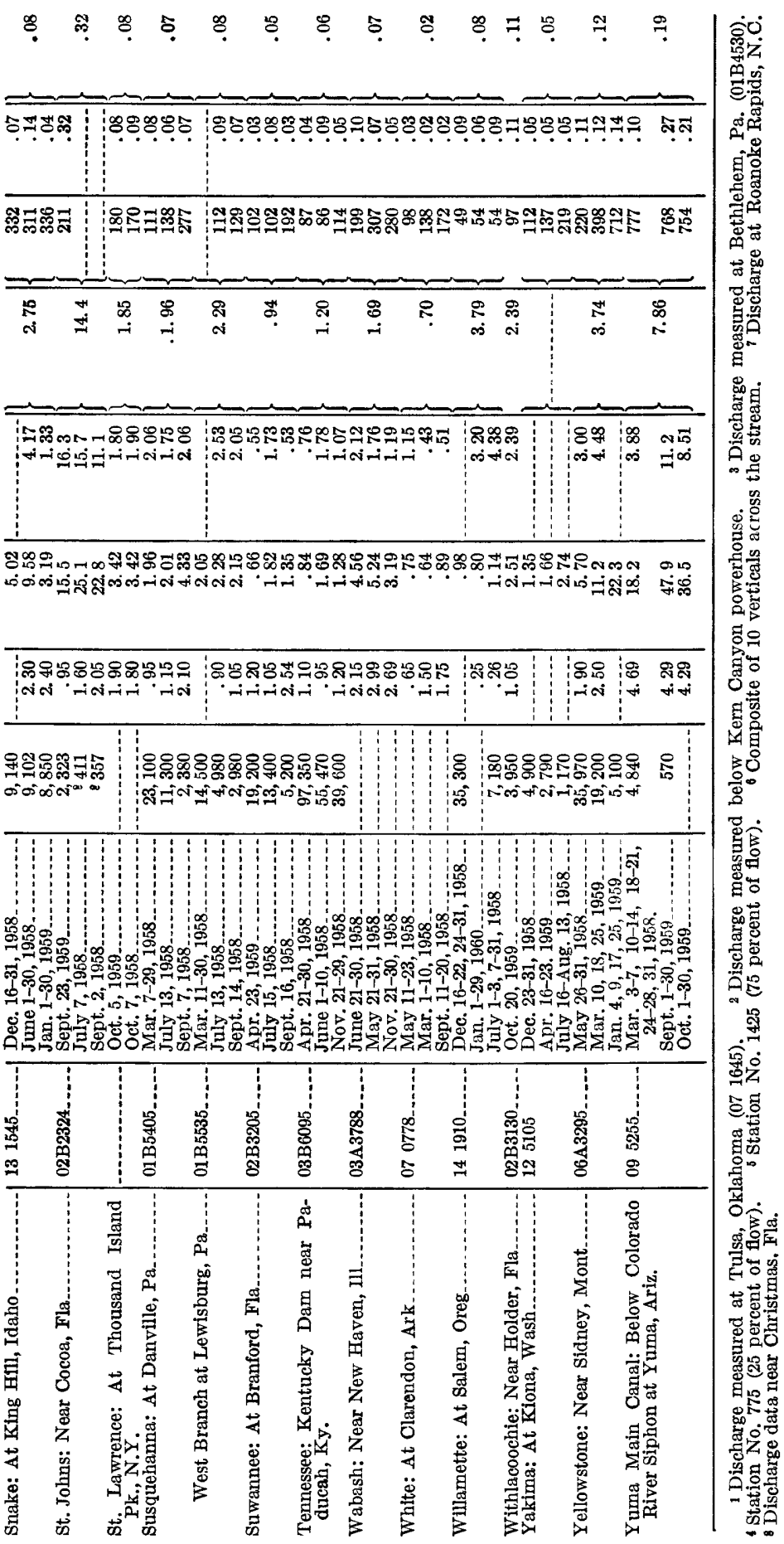




\section{Chemistry of Strontium}

\section{in Natural Water}

GEOLOGICAL SURVEY WATER-SUPPLY PAPER 1496

This water-supply paper was printed as separate chapters $A-D$

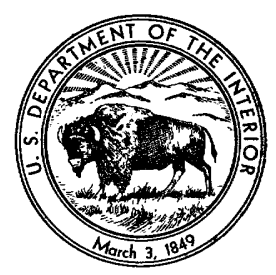




\section{UNITED STATES DEPARTMENT OF THE INTERIOR}

STEWART L. UDALL, Secretary

\section{GEOLOGIGAL SURVEY}

Thomas B. Nolan, Director

The U.S. Geological Survey Library has cataloged this publication as follows:

\section{U.S. Geological Survey.}

Chemistry of strontium in natural water. Washington, U.S. Govt. Print. Off., 1962.

iii, 97 p. illus., diagrs., tables. $24 \mathrm{~cm}$. (Its Water-supply paper 1496)

Issued as separate chapters A-D.

Includes bibliographies.

1. Strontium. 2. Water-Analysis. I. Title. (Series) 


\section{CONTENTS}

[The letters in parentheses preceding the titles are those used to designate the separate chapters]

(A) A survey of analytical methods for the determination of strontium in

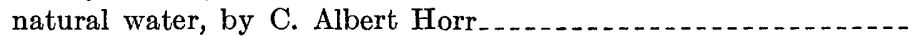

(B) Copper-spark method for spectrochemical determination of strontium in water, by Marvin W. Skougstad...

(C) Flame photometric determination of strontium in natural water, by C. Albert Horr.

(D) Occurrence and distribution of strontium in natural water, by Marvin W. Skougstad and C. Albert Horr.... 55 